\title{
Comparative Analysis of Seasonal Changes in Soil Contaminations from Polycyclic Aromatic Hydrocarbons at Solid Waste Dumpsites in Port Harcourt, Nigeria
}

\author{
Loremikan, A.G. Ngah, S.A. Abam, T.K.S. Ubong, I.U. \\ Institute of Geo-Sciences and Space Technology \\ Rivers state university, Nkporlu- Oroworukwo, Portharcourt, Rivers State, Nigeria
}

Abstracts:

\section{$>$ Background}

Polycyclic Aromatic Hydrocarbons are generated in solid waste dumpsites where disused wastes are dumped. This study investigated the concentration levels of PAHs in the soil at solid waste dumpsites located in Markets, Semi-industrial and Residential areas in Rainy and Dry seasons.

\section{$>$ Materials and Method}

Fifteen soil samples were collected in each season and analyzed using Gas Chromatography at the Rivers State University, Institute of Pollution Studies Research Laboratory. Each of the season laboratory data were analysed using descriptive statistics viz mean \pm standard deviation as well as inferential statistics such as 2 sample T-test at $5 \%$ level of significance. Hierarchical Cluster Analysis (HCA) and Principal Components Analysis ( PCA)where applied on the measured data to determine the sources of contamination as well as the level of pollution by comparing with the control sites.

\section{$>$ Results}

High Molecular weight (HMW) PAHs which are toxicologically relevant were detected in all the three classified dumpsites in both seasons with highest value of Chrysene in residential dumpsites during rainy season and Dibenez(a,h)anthracene in dry season. Each of classified dumpsites has average total PAHs values greater than $1 \mathrm{mg} / \mathrm{kg}(>1)$ in Rainy season while in dry season, only market dumpsites have an average greater than $1 \mathrm{mg} / \mathrm{kg}$. The order of the level of pollution in rainy season is observed to be: Control site $<$ Semi-industrial area $<$ Market area $<$ Residential area is highly polluted (HP). the Market area is moderately polluted (MP) while the Semi-industrial area is less polluted (LP). While for Dry Season, the order of the level of pollution is Control site $<$ Residential area $<$ Semi-industrial area<Market area or the Market area is highly polluted (HP), the Semi-industrial area is moderately polluted (MP) while the residential area is less polluted (LP).

\section{$>$ Conclusion}

The total value of Polycyclic Aromatic Hydrocarbon $\sum$ PAHs signifies 'Heavily contaminated' of the soil at all the dumpsites in Rainy season. However, during dry season, only the $\sum$ PAHs values in Market dumpsites is classified "Heavily contaminated" while Semi- industrial and Residential are classified weekly contaminated. This study shows that presence of PAH in all dumpsite where municipal, domestic household solid waste are dumped and thus indicated that the properties and qualities of the soil in these areas are adversely affected. It is recommended that solid waste evacuation should be done frequently from all the dumpsites to the main government reserved dumpsites.

Keywords:- Polycyclic Aromatic Hydrocarbon, Solid Waste, Dumpsites, Contamination, Soil. Dry \& Rainy Seasons.

\section{INTRODUCTION}

Soils may become contaminated by the accumulation of heavy metals, metalloids and polycyclic aromatic hydrocarbons through emissions from the rapidly expanding industrial areas, mine tailings, disposal of high metal wastes, leaded gasoline and paints, land application of fertilizers, animal manures, sewage sludge, pesticides, wastewater irrigation, coal combustion residues, spillage of petrochemicals, and atmospheric deposition [6].

The first point of dumping household disused products which are known as solid waste in Port Harcourt city is dumpsites located nearer to the depositor. Polycyclic Aromatic Hydrocarbons (PAHs) are ubiquitous environmental pollutants generated primarily during the incomplete combustion of organic materials (e.g. coal, oil, petrol, and wood). The study of this compounds is mainly due to their carcinogenic and widespread occurrence in environmental components, including surface soil ${ }^{4}$. Plant can absorb PAHs from soils through their roots and translocate them to other plant parts. Meanwhile, uptake rates are generally governed by concentration, water solubility and their physicochemical state as well as soil type. There is therefore need to carry out this research to generate more information and also evaluate the level and 
health risk effect of the Polycyclic Aromatic Hydrocarbons generated from household solid waste being dumped at the waste dumpsites areas nearer to human habitation.

The following three types: pyrogenic, petrogenic, and biological are the major PAH sources to the environment. In a process called pyrolysis, Pyrogenic PAHs are formed whenever organic substances are exposed to high temperatures under low oxygen or no oxygen conditions. PAHs formed during crude oil maturation and similar processes are called petrogenic. Such petrogenic PAHs are common due to the widespread transportation, storage, and use of crude oil and crude oil products. On the other hand, it is not well-known that PAHs can be produced biologically. For example, they can be synthesized by certain plants and bacteria or formed during the degradation of vegetative matter.

Ifemeje [5] studied distribution of polycyclic aromatic hydrocarbons (PAHs) in soils from Onitsha municipal active and dormant solid waste dumpsites. The study showed that Low molecular weight PAHs were not detected in both active and dormant dumpsite. High molecular weight PAHs (HMW PAHs) were predominant in soil from active site. Among the HMW PAHs, Benzo (a) pyrene was highest followed by $\operatorname{Benzo}(\mathrm{k})$ fluoranthene and Indeno (1,2,3-cd) pyrene and the least was 1,2 Benzo(a)anthracene. The medium molecular weight PAHs (MMW PAHs) Fluoranthene occurred sparingly in the active dumpsite.

Olajire [7], investigated the distribution and sources of PAHs in soil as well as PAHs profiles in areas with anthropogenic pollution in the Niger Delta (Nigeria) such as Warri and Ughelli. PAH concentrations in soil samples from Warri Refinery, Tanker Loading point and Ugboko via Rapele oil field were quite high (the mean ÓPAH concentrations were 433, 402 and $384 \mathrm{ug} / \mathrm{kg}$ dry weight respectively). The dominant PAHs in soil samples were pyrene, naphthalene and benzo[k]fluoranthene. Two and three ring aromatic hydrocarbons predominated in soil samples from Ughelli West, Tanker Loading point and Delta Steel Company, which is indicative of petrogenic origin.

Godson [4], studies determined, in comparison with guideline limits, the levels of Polycyclic Aromatic Hydrocarbons (PAH) in the soils at Eleme (highly industrialized) and Ahoada East (less industrialized) communities in the Niger Delta Area. The highest levels of Benzo(a)pyrene (BaP) (1.54 x $105 \mathrm{ng} / \mathrm{kg})$ were recorded at Onne. Soil samples close to the Petroleum Refinery at Alesa recorded the highest total PAH concentration (2.30 $\mathrm{x} 106 \mathrm{ng} / \mathrm{kg}$ ) even though this was slightly lower than the EPA guideline value of $2.5 \times 106 \mathrm{ng} / \mathrm{kg}$. . The highest $\mathrm{BaP}$ concentrations were observed at Ahoada town $(1.57 \times 105$ $\mathrm{ng} / \mathrm{kg}$ ). Also the highest total PAH levels (3.67 x 105 $\mathrm{ng} / \mathrm{kg}$ ) were recorded at Odiabidi and this was lower than the levels at Eleme and EPA guideline limits $(\mathrm{P}<0.05)$. The study showed that the communities at Eleme when compared to Ahoada East may be more vulnerable to hazards associated with increased exposure to Soil PAH.

Adebola [1], studied the levels of heavy metals and PAHs in soils of e-waste dumpsites in Lagos and Ibadan, Nigeria. The total PAHs ranged from 1,756-2,224 $\mu \mathrm{g} / \mathrm{kg}$ at the $0-15 \mathrm{~cm}$ level, $1,664-2,152 \mu \mathrm{g} / \mathrm{kg}$ at $15-30 \mathrm{~cm}$ and 278 $\mu \mathrm{g} / \mathrm{kg}$ in the top- and sub-soil of the control site. The study also showed that high molecular weight PAHs were the predominant PAHs throughout the dumpsites. In the soils of e-waste dumpsites in Lagos and Ibadan, the LMW/HMW range of $0.55-0.69$ and $0.48-0.65$ at the $0-15$ $\mathrm{cm}$ level, indicated pollution of pyrolytic origin.

Fagbote [3], investigated Polycyclic aromatic hydrocarbons (PAHs) and polychlorinated biphenyls (PCBs) in soils of Agbabu, Nigeria. . The maximum sum of concentrations of PAHs $(\Sigma \mathrm{PAH})$ was $0.07 \pm 0.036 \mathrm{ppm}$ in the dry season, and $0.69 \pm 0.19 \mathrm{ppm}$ in the rainy season. Most of the PAH concentrations obtained were within the expected limits for a rural environment. However, in the rainy season, $0.20 \pm 0.04 \mathrm{ppm}$ for $\operatorname{Benzo}(\mathrm{b})$ flouranthene, $0.21 \pm 0.05 \mathrm{ppm}$ for Benzo $(\mathrm{g}, \mathrm{h}, \mathrm{i})$ perylene and $0.32 \pm$ $0.04 \mathrm{ppm}$ for Indenol $(1,2,3-\mathrm{cd})$ pyrene exceeded the expected limit. In the dry season, there was no significant relationship $(\mathrm{r} 2=0.002)$ between mean concentrations and percentage soil organic carbon while there was significant correlation $(\mathrm{r} 2=0.57)$ in this relationship in the rainy season. The predominance of 4 - 6 ring PAHs and the ratios between pairs of individual PAHs showed that the PAHs were from pyrolytic sources.

Tekleweini [9], evaluated the distribution, potential sources, and ecological and cancer risks of eleven polycyclic aromatic hydrocarbons from Huangpi soils in Wuhan, central China. The sum mean concentrations of the polycyclic aromatic hydrocarbons were 138.93 and $154.99 \mu \mathrm{g} \mathrm{kg}-1$ in the $0-10 \mathrm{~cm}$ and $10-20 \mathrm{~cm}$ soil depths, respectively. Benzo[a]pyrene and fluorene were the most abundant compounds in the $0-10 \mathrm{~cm}$ and $10-20 \mathrm{~cm}$ soil depths, respectively.

Most past studies on PAH are carried out on soil suspected to have been contaminated with either hydrocarbon products or area where combustion has taken place. There are various domestic solid waste dumpsites that are in markets, semi-industrial and residential areas. These dumpsites are the first place where domestic solid waste is dumped. The presence of PAHs at these domestic solid waste dumpsites are generally not considered since combustion is not imagined at these sites most especially the hydrocarbon presence considered negligible. 
ISSN No:-2456-2165

\begin{tabular}{|c|c|c|c|}
\hline PAHs & Chemical Formula & Molecular weight & No of Rings \\
\hline Low molecular weight & & & 2 \\
\hline Naphthalene & $\mathrm{C}_{10} \mathrm{H}_{8}$ & 128 & 3 \\
\hline Acenaphthylene & $\mathrm{C}_{12} \mathrm{H}_{8}$ & 152 & 3 \\
\hline Acenaphthene & $\mathrm{C}_{12} \mathrm{H}_{10}$ & 154.21 & 3 \\
\hline Fluorene & $\mathrm{C}_{13} \mathrm{H}_{10}$ & 166.2 & 3 \\
\hline Phenanthrene & $\mathrm{C}_{14} \mathrm{H}_{10}$ & 178.2 & 3 \\
\hline Anthracene & $\mathrm{C}_{14} \mathrm{H}_{10}$ & 178.2 & 4 \\
\hline Medium Molecular weight & & & 4 \\
\hline Fluoranthene & $\mathrm{C}_{16} \mathrm{H}_{10}$ & 202.16 & 4 \\
\hline Pyrene & $\mathrm{C}_{16} \mathrm{H}_{10}$ & 202.3 & 4 \\
\hline High Molecular weight & $\mathrm{C}_{18} \mathrm{H}_{12}$ & 228.3 & 5 \\
\hline Chrysene & $\mathrm{C}_{18} \mathrm{H}_{12}$ & 228.89 & 5 \\
\hline Benzo(a)anthracene & $\mathrm{C}_{20} \mathrm{H}_{12}$ & 251.3 & 6 \\
\hline Benzo(k)fluoranthene & $\mathrm{C}_{20} \mathrm{H}_{12}$ & 251.3 & 6 \\
\hline Benzo(a)pyrene & $\mathrm{C}_{22} \mathrm{H}_{12}$ & 276.3 & 6 \\
\hline Indono(1,2,3-Cd)pyrene & $\mathrm{C}_{22} \mathrm{H}_{12}$ & 276.3 & 278.35 \\
\hline Benzo(g,h,i)pevylene & $\mathrm{C}_{22} \mathrm{H}_{12}$ & & \\
\hline Dibenzo(a,h)anthracen & $\mathrm{C}_{2}$ & & \\
\hline Tabl:- & & & \\
\hline
\end{tabular}

Table 1:- Classification of Polycyclic Aromatic Hydrocarbon (PAHs) Based on Molecular Weight

Source: ATSDR (Agency for Toxic Substances and Disease Registry). Atlanta, GA, 1995;458

\section{Fate and Transport of PAHs in Soil}

PAHs are adsorbed strongly to the organic fraction of soils and sediments. Some PAHs may be degraded biologically in the aerobic soil layer, but this process is slow because sorption to the organic carbon fraction of the soil reduces the bioavailability. However, leaching of PAHs from the soil surface layer to groundwater is assumed to be negligible, although detectable concentrations in groundwater have been reported. Polycyclic aromatic hydrocarbons are removed from soils principally by volatilization and microbial activity, the extent of which varies, depending on factors such as temperature, soil type, presence of other contaminants, and previous contamination level. Again, low molecular weight PAHs volatilize more rapidly than high molecular weight PAHs. Figure 1 below shows the schematic view of the fate and transport of PAHs in soil.

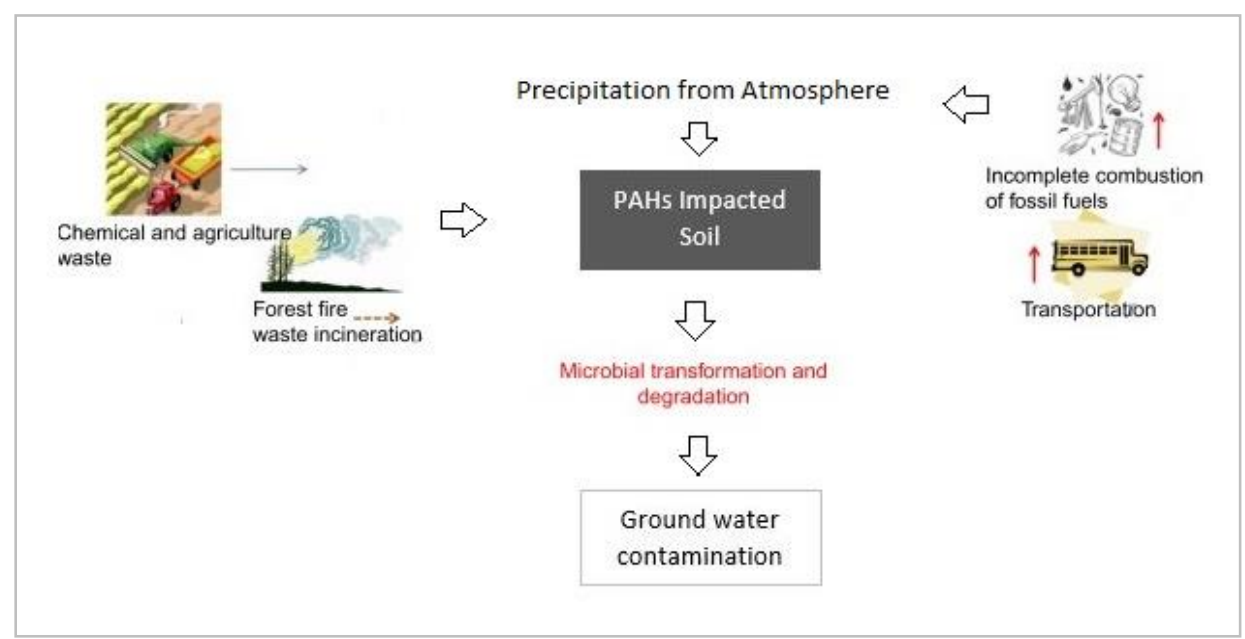

Fig 1:- Fate and Transport of PAHs in Soil

\section{MATERIALS AND METHODS}

Port Harcourt is the capital and largest city of Rivers State, Nigeria. It lies along the Bonny River and is located in the Niger Delta. As of 2016, the Port Harcourt urban area has an estimated population of 1,865,000 inhabitants, up from 1,382,592 as of 2006. The urban area (Port Harcourt metropolis), on the other hand, is made up of the local government area itself and parts of Obio-Akpor and Eleme accordingly. Port Harcourt, which is the current capital of
Rivers State, is highly congested as it is the only major city of the state.

The area of study is in Port Harcourt metropolis, Rivers State. The area is bounded geographically by latitudes $4^{\circ} 46^{\prime} \mathrm{N}$ to $5^{\circ} 00^{\prime} \mathrm{N}$ and longitudes $6^{\circ} 55^{\prime} \mathrm{E}$ to $7^{\circ} 03^{\prime}$ E. Open dump sites are the most common waste disposal methods in Port Harcourt and many cities in Nigeria. Open dump sites are found in several residential, Markets and semi - industrial locations around the city, for example, Rukpokwu village, Rumuokoro, Rumuomasi, Diobu, 
Marine base, and Borokiri, to mention a few. The dumpsites within the study area and the locations of all the sampling points were recorded with the aid of a garmin Global Positioning System (GPS). include; Residential, Markets \& Industrial as stated below:

Soil samples for PAH determination were collected in aluminum foil from the various dumpsites. An auger was used for collecting soil samples at shallow depth of about 1 $-15 \mathrm{~cm}$. For each sampling point, three samples were taken from the same area and mixed thoroughly to form a composite homogenous sample. Sampling tools were washed with water and dried before the next sample was collected. About $1 \mathrm{~kg}$ of soil sample were collected at each sampling site in order to ensure that enough fine-grained material would be available for analysis. Fifteen (15) soil samples were collected for each season, from a different dumpsite (Table 3). Samples were labeled properly including date of collection, location and code number of soil samples.

$2 \mathrm{~g}$ samples were weighed into a clean extraction container. $20 \mathrm{ml}$ of extraction solvent (hexane) was added into the sample, mixed thoroughly and allowed to settle. The mixture was carefully filtered into solvent-rinsed extraction bottles using filter paper fitted into Buchner funnels. The extracts were concentrated to $2 \mathrm{ml}$ and then transferred for clean-up/separation. $1 \mathrm{~cm}$ of moderately packed glass wool was placed at the bottom of $10 \mathrm{~mm}$ I.D (internal diameter) $\times 250 \mathrm{~mm}$ long chromatographic column. Slurry of $2 \mathrm{~g}$ activated silica in $10 \mathrm{ml}$ dichloromethane was prepared and placed into the chromatographic column. To the top of the column was added $0.5 \mathrm{~cm}$ of sodium sulphate. The column was rinsed with additional $10 \mathrm{ml}$ of dichloromethane. The column was pre-eluted with $20 \mathrm{ml}$ of hexane. This was allowed to flow through the column at the rate of about 2 minutes until the liquid in the column was just above the sodium sulphate layer. Immediately, $1 \mathrm{ml}$ of the extracted sample was transferred into the column. The extraction bottle was rinsed with $1 \mathrm{ml}$ of hexane and the dissolved extract was added to the column as well. The stop cork of the column was opened and the eluent was collected in a $10 \mathrm{ml}$ graduated measuring cylinder. Just prior to exposure of the sodium sulphate layer to air, hexane was added to the column in $1-2 \mathrm{ml}$ increments. Accurately measured volume of $8-10 \mathrm{ml}$ of the volatile aromatics (BTEX) as applicable.

Gas Chromatographic analysis: The concentrated aliphatic or aromatic fractions were transferred into labelled glass vials with Teflon or rubber crimp caps for GC analysis. $1 \mathrm{ul}$ of the concentrated sample was injected by means of an hypodermic syringe through a rubber septum into the column. Separation occurs as the vapour constituent partitions between the gas and liquid phases. The sample was automatically detected as it emerged from the column by the FID detector whose response is dependent upon the composition of the vapour.

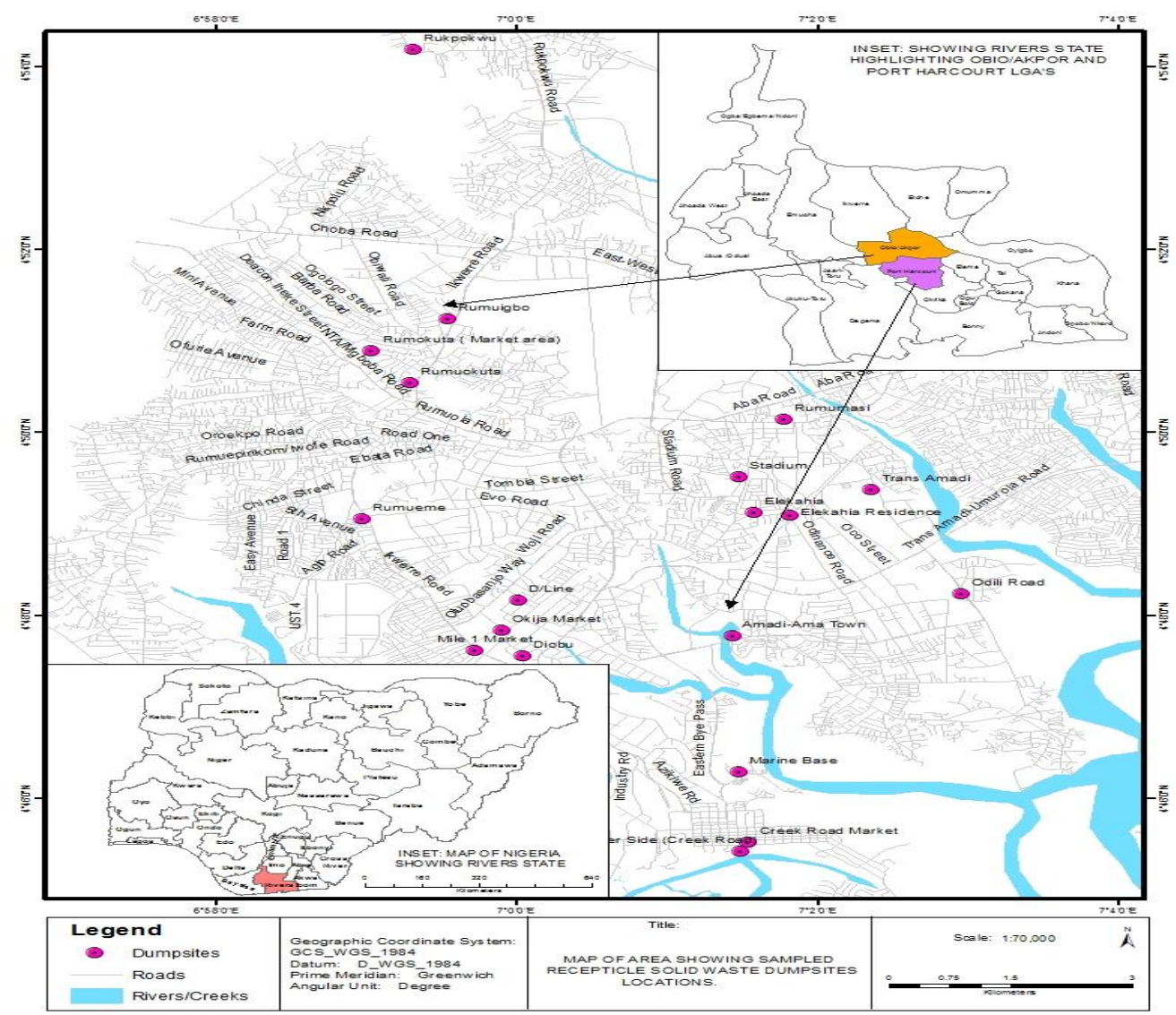

Fig 2:- Map of study area, Port Harcourt City , Nigeria 
ISSN No:-2456-2165

\begin{tabular}{|c|c|c|c|c|}
\hline S/no & & Location Name & Codes & GPS \\
\hline \multirow{2}{*}{1} & \multirow{10}{*}{ Market Areas (MA) } & \multirow{2}{*}{ Okija Market } & \multirow{2}{*}{ MA01 } & $\mathrm{N} 04^{\circ} 47^{\prime} 50.5^{\prime \prime}$ \\
\hline & & & & E $006^{\circ} 59^{\prime} 54.6^{\prime \prime}$ \\
\hline \multirow{2}{*}{2} & & \multirow{2}{*}{ Creek Road Market } & \multirow{2}{*}{ MA02 } & $\mathrm{N} 04^{\circ} 45^{\prime} 31.5^{\prime \prime}$ \\
\hline & & & & E $007^{\circ} 01^{\prime} 33.0^{\prime \prime}$ \\
\hline \multirow{2}{*}{3} & & \multirow{2}{*}{ Rumokuta (Market area) } & \multirow{2}{*}{ MA03 } & $\mathrm{N} 04^{\circ} 51^{\prime \prime} 58.2^{\prime \prime}$ \\
\hline & & & & E $007^{\circ} 00^{\prime} 02.8^{\prime \prime}$ \\
\hline \multirow{2}{*}{4} & & \multirow{2}{*}{ Water side (Creek road) } & \multirow{2}{*}{ MA04 } & $\mathrm{N} 04^{\circ} 45^{\prime} 31.2^{\prime \prime}$ \\
\hline & & & & E $007^{\circ} 01^{\prime} 27.4^{\prime \prime}$ \\
\hline \multirow{2}{*}{5} & & \multirow{2}{*}{ Mile 1 Market } & \multirow{2}{*}{ MA05 } & N 04 47'37.2”' \\
\hline & & & & E $006^{\circ} 59^{\prime} 43.8^{\prime \prime}$ \\
\hline \multirow{2}{*}{6} & \multirow{10}{*}{$\begin{array}{l}\text { Semi Industrial area. } \\
\text { (SIA) }\end{array}$} & \multirow{2}{*}{ Trans Amadi } & \multirow{2}{*}{ SIA01 } & $\mathrm{N} 04^{\circ} 49^{\prime} 22.7^{\prime \prime}$ \\
\hline & & & & E $007^{\circ} 02^{\prime} 22.1^{\prime \prime}$ \\
\hline \multirow{2}{*}{7} & & \multirow{2}{*}{ Stadium road } & \multirow{2}{*}{ SIA02 } & N 04 49’30.9’' \\
\hline & & & & $\mathrm{E} 007^{\circ} 01^{\prime} 29.2^{\prime \prime}$ \\
\hline \multirow{2}{*}{8} & & \multirow{2}{*}{ Odili Road } & \multirow{2}{*}{ SIA03 } & $\mathrm{N} 04^{\circ} 48^{\prime} 14.2^{\prime \prime}$ \\
\hline & & & & E $007^{\circ} 02^{\prime} 57.7^{\prime \prime}$ \\
\hline \multirow{2}{*}{9} & & \multirow{2}{*}{ Elekohia } & \multirow{2}{*}{ SIA04 } & $\mathrm{N} 04^{\circ} 49^{\prime} 07.8^{\prime \prime}$ \\
\hline & & & & E $007^{\circ} 01^{\prime} 35.0^{\prime \prime}$ \\
\hline \multirow{2}{*}{10} & & \multirow{2}{*}{ D/Line } & & $\mathrm{N} 04^{\circ} 48^{\prime} 10.1^{\prime \prime}$ \\
\hline & & & SIAOS & E $007^{\circ} 00^{\prime} 00.8^{\prime \prime}$ \\
\hline 11 & & Porolivi & $\mathrm{D} \wedge 00$ & $\mathrm{~N} 04^{\circ} 44^{\prime} 47.4^{\prime \prime}$ \\
\hline 11 & & DOIOKIII & KAOI & E $007^{\circ} 02^{\prime} 29.5^{\prime \prime}$ \\
\hline 12 & & Marine base & $\mathrm{RA} 02$ & 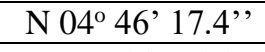 \\
\hline & & & KAOL & E $007^{\circ} 01^{\prime} 29.0^{\prime \prime}$ \\
\hline 13 & Residential Areas (RA) & Elekohia Residence & $\mathrm{RA} 03$ & $\mathrm{~N} 04^{\circ} 49^{\prime} 06.2^{\prime \prime}$ \\
\hline 13 & Kesidential Areas (KA) & Elekonia Kesidence & KA03 & E $007^{\circ} 01^{\prime} 49.4^{\prime \prime}$ \\
\hline 14 & & Dirbu recidontiol & $\mathrm{D} \wedge 004>0$ & N 04 47'33.6”' \\
\hline 14 & & Diodu resiacntial & KAO4 & E $007^{\circ} 00^{\prime} 03.0^{\prime \prime}$ \\
\hline 15 & & Ruknokwu village & RA05 & $\mathrm{N} 04^{\circ} 54^{\prime} 11.7^{\prime}$ \\
\hline $1 J$ & & кикрок wu viाlage & KAOS & E $006^{\circ} 59^{\prime} 19.0^{\prime \prime}$ \\
\hline
\end{tabular}

Table 2:- Locations for soil sampling

\section{Statistical Analysis}

Sample data analysis: After collection of all the necessary data, further data analysis techniques such as ANOVA and Correlation matrix were conducted using statistical package for social science (SPSS) of version 20.0. ANOVA will be used to make comparisons among the different groups at $95 \%$ confidence limit. Data analysis was carried out using 2-sample t-test (carried out in Minitab 18, a statistical software) to determine the level of significance and make comparisons among the different groups at $95 \%$ confidence limit.

\section{> Paired Sample T-test}

The paired sample t-test, sometimes called the dependent sample t-test, is a statistical procedure used to determine whether the mean difference between two sets of observations is zero. In a paired sample t-test, each subject or entity is measured twice, resulting in pairs of observations. Its similar data collected from different locations. Since, the same parameters where measured at the different sampling locations and the control site we use the paired sample T-test to compare the result. This test was carried out in Minitab 19 software. Like many statistical procedures, the paired sample t-test has two competing hypotheses, the null hypothesis and the alternative hypothesis.

\section{> Hierarchical Cluster Analysis (HCA)}

Complete Linkage and Centroid Linkage Method, and Principal Component analysis were used for further Heavy metals analysis. Hierarchical cluster analysis (HCA) is a combination of techniques to classify large data into clusters on the basis of similarities or dissimilarities. Thus, resulting groups are similar to each other but distinct from other groups. Researchers have widely applied HCA for classification and interpreting experimental data [10]. In the present study, HCA was used to group sampling points based on their similarities in dump sites and to detect links between PAHs constituents. A combination of complete linkage methods and centroid linkage method of Euclidian and squared Euclidian were applied to all data sets. The HCA shows the dendrograms for the various methods applied. The complete linkage method was applied to perform cluster analysis in Minitab 18 software using multivariate under stat,

\section{The Principal Components Analysis (PCA)}

Is the powerful multivariate method to identify the patterns in data and expressing their similarities and differences. Principal component analysis (PCA) was used to provide an overview of the distribution pattern of heavy metals in waste dump site. This method is particularly useful when the variables within the data set are highly 
correlated. Correlation indicates that there is redundancy in the data. Due to this redundancy, PCA can be used to reduce the original variables into a smaller number of new variables (principal components) explaining most of the variance in the original variables. The data are represented in the $\mathrm{X}-\mathrm{Y}$ coordinate system. The dimension reduction is achieved by identifying the principal directions, called principal components, in which the data varies. PCA assumes that the directions with the largest variances are the most "important" (i.e., the most principal). The right axis is the first principal direction along which the samples show the largest variation. The left axis is the second most important direction and it is orthogonal to the right axis.

\section{RESULTS}

Table 3, and Table 6, shows the respective rainy and dry season laboratory results of PAH on each soil samples from the fifteen sampling locations that are classified into residential, market and semi-industrial locations respectively. The average of each of the 14 PAHs are illustrated in Table 4 for Rainy season and Table 7 for dry season. Table 5 and Table 8 shows the season Range, Mean and SD Concentrations for rainy and dry season respectively. Table: 9 shows the average PAHs Concentration at the Dumpsites in RAINY and DRY seasons Fig. 2: shows the general graphical comparative analysis of PAHs Concentration at the dumpsites in RAINY and DRY seasons. The graphical interpretation shows that concentration of HMWPAH are more at all dumpsites during rainy season than in Dry season. The highest concentration of total PAHs with value $4.625 \mathrm{mg} / \mathrm{kg}$ is observed at Diobu dumpsite located in residential area in rainy season (Table 3), while in dry season(Table 6), Creek road market dumpsite has the highest total PAHs concentration of $1.89 \mathrm{mg} / \mathrm{kg}$.

\begin{tabular}{|c|c|c|c|c|c|c|c|c|c|c|c|c|c|c|c|c|c|}
\hline & & & \multicolumn{5}{|c|}{ Market Area } & \multicolumn{5}{|c|}{ Semi - Industrial } & \multicolumn{5}{|c|}{ Residential } \\
\hline & & & \begin{tabular}{|c|} 
Okija \\
Market
\end{tabular} & \begin{tabular}{|c|} 
Creek \\
Road \\
Market
\end{tabular} & $\begin{array}{c}\text { Rumokuta } \\
\text { (Market } \\
\text { area) }\end{array}$ & \begin{tabular}{|c|} 
Water \\
side \\
(Creek \\
road)
\end{tabular} & \begin{tabular}{|c|} 
Mile 1 \\
Market
\end{tabular} & \begin{tabular}{|c|} 
Trans \\
Amadi \\
\end{tabular} & $\begin{array}{c}\text { Stadium } \\
\text { Road }\end{array}$ & \begin{tabular}{|c|} 
Odili \\
Road
\end{tabular} & Elekohia & D/Line & Borokin & $\begin{array}{c}\text { Marine } \\
\text { Base }\end{array}$ & Elekohia & Diobu & $\begin{array}{l}\text { Rukpokwu } \\
\text { village }\end{array}$ \\
\hline & & & $\begin{array}{c}\text { N 04o } \\
47^{\prime} \\
50.5^{\prime \prime} \\
\text { E 006o } \\
59^{\prime} \\
54.6^{\prime \prime} \\
\end{array}$ & \begin{tabular}{|c|}
$\mathrm{N} 04 \mathrm{o}$ \\
$45^{\prime}$ \\
$31.5^{\prime \prime}$ \\
$\mathrm{E} 007 \mathrm{o}$ \\
$01^{\prime}$ \\
$33.0^{\prime \prime}$ \\
\end{tabular} & $\mid \begin{array}{c}04051^{\prime \prime} \\
58.2^{\prime \prime} \\
\text { E 0070 00 } \\
02.8^{\prime \prime} \\
\end{array}$ & \begin{tabular}{|c|} 
N 04o \\
$45^{\prime}$ \\
$31.2^{\prime \prime}$ \\
E 007o \\
$01^{\prime}$ \\
$27.4^{\prime \prime}$ \\
\end{tabular} & \begin{tabular}{|c|} 
N 04o \\
$47^{\prime}$ \\
$37.2^{\prime \prime}$ \\
E 006o \\
$59^{\prime}$ \\
$43.8^{\prime \prime}$ \\
\end{tabular} & \begin{tabular}{|c|} 
N 04o \\
$49^{\prime}$ \\
$22.7^{\prime \prime}$ \\
E 007o \\
$02^{\prime}$ \\
$22.1^{\prime \prime}$ \\
\end{tabular} & \begin{tabular}{|c} 
N 04o \\
$49^{\prime}$ \\
$30.9^{\prime \prime}$ \\
E 007o \\
$01^{\prime}$ \\
$29.2^{\prime \prime}$ \\
\end{tabular} & \begin{tabular}{|c|}
$\mathrm{N} \mathrm{040}$ \\
$48^{\prime}$ \\
$14.2^{\prime \prime}$ \\
$\mathrm{E} 007 \mathrm{o}$ \\
$02^{\prime}$ \\
$57.7^{\prime \prime}$ \\
\end{tabular} & $\begin{array}{c}\text { N 04o } \\
49^{\prime} \\
07.8^{\prime \prime} \\
\text { E 007o } \\
01^{\prime} \\
35.0^{\prime \prime} \\
\end{array}$ & \begin{tabular}{|c|} 
N 04o \\
$48^{\prime}$ \\
$10.1^{\prime \prime}$ \\
E 007o \\
$00^{\prime}$ \\
$00.8^{\prime \prime}$ \\
\end{tabular} & \begin{tabular}{|c|} 
N 040 \\
$44^{\prime}$ \\
$47.4^{\prime \prime}$ \\
E 007o \\
$02^{\prime}$ \\
$29.5^{\prime \prime}$ \\
\end{tabular} & \begin{tabular}{|c|} 
N 04o \\
$46^{\prime}$ \\
$17.4^{\prime \prime}$ \\
E 007o \\
$01^{\prime}$ \\
$29.0^{\prime \prime}$ \\
\end{tabular} & \begin{tabular}{|c|} 
N 04o \\
$49^{\prime}$ \\
$06.2^{\prime \prime}$ \\
E 007o \\
$01^{\prime}$ \\
$49.4^{\prime \prime}$ \\
\end{tabular} & \begin{tabular}{|c} 
N 04o \\
$47^{\prime}$ \\
$33.6^{\prime \prime}$ \\
E 007o \\
$00^{\prime}$ \\
$03.0^{\prime \prime}$
\end{tabular} & $\begin{array}{c}\text { N } 04054^{\prime} \\
11.7^{\prime \prime} \\
\text { E 006059' } \\
19.0^{\prime \prime}\end{array}$ \\
\hline S/no & PAH name & $\begin{array}{l}\text { No of } \\
\text { rings }\end{array}$ & MA001 & MA002 & MA003 & MA004 & MA005 & SIA001 & SIA002 & SIA003 & SIA004 & SIA005 & RA001 & RA002 & RA003 & RA004 & RA005 \\
\hline 1 & Naphthalene & Two & 0.005 & 0.055 & 0.000 & 0.000 & 0.000 & 0.000 & 0.000 & 0.000 & 0.000 & 0.048 & 0.000 & 0.000 & 0.000 & 0.000 & 0.001 \\
\hline 2 & Acenaphthylene & Two & 0.039 & 0.019 & 0.003 & 0.003 & 0.000 & 0.000 & 0.079 & 0.000 & 0.000 & 0.006 & 0.000 & 0.000 & 0.012 & 0.000 & 0.026 \\
\hline 3 & Acenaphthene & Two & 0.209 & 0.026 & 0.013 & 0.001 & 0.009 & 0.017 & 0.014 & 0.002 & 0.004 & 0.007 & 0.003 & 0.007 & 0.003 & 0.004 & 0.005 \\
\hline 4 & Fluorene & Two & 0.120 & 0.007 & 0.009 & 0.004 & 0.007 & 0.019 & 0.093 & 0.002 & 0.008 & 0.005 & 0.008 & 0.002 & 0.005 & 0.005 & 0.005 \\
\hline 5 & Phenanthrene & Three & 0.042 & 0.007 & 0.013 & 0.007 & 0.013 & 0.229 & 0.075 & 0.010 & 0.011 & 0.012 & 0.006 & 0.011 & 0.019 & 0.004 & 0.007 \\
\hline 6 & Anthracene & Three & 0.015 & 0.010 & 0.007 & 0.002 & 0.012 & 0.036 & 0.274 & 0.009 & 0.009 & 0.024 & 0.005 & 0.007 & 0.012 & 0.004 & 0.003 \\
\hline 7 & Fluoranthene & Three & 0.010 & 0.023 & 0.025 & 0.023 & 0.011 & 0.036 & 0.379 & 0.018 & 0.014 & 0.044 & 0.009 & 0.027 & 0.016 & 0.010 & 0.011 \\
\hline 8 & Pyrene & Four & 0.113 & 0.007 & 0.011 & 0.001 & 0.004 & 0.003 & 0.022 & 0.002 & 0.005 & 0.024 & 0.002 & 0.002 & 0.010 & 0.018 & 0.001 \\
\hline 9 & Benz(a)anthracene & Four & 0.009 & 0.006 & 0.031 & 0.006 & 0.003 & 0.010 & 0.032 & 0.004 & 0.004 & 0.014 & 0.002 & 0.009 & 0.016 & 0.106 & 0.009 \\
\hline 10 & Chrysene & Four & 0.141 & 0.212 & 0.641 & 0.365 & 0.741 & 0.296 & 0.054 & 0.434 & 0.775 & 0.455 & 0.678 & 0.656 & 0.765 & 2.839 & 0.418 \\
\hline 11 & Benzo(b)Fluoranthene & Four & 0.156 & 0.268 & 0.420 & 0.078 & 0.180 & 0.165 & 0.180 & 0.216 & 0.065 & 0.238 & 0.342 & 0.156 & 0.265 & 0.235 & 0.035 \\
\hline 12 & Benzo(k)fluoranthene & Four & 0.090 & 0.145 & 0.072 & 0.083 & 0.045 & 0.079 & 0.033 & 0.009 & 0.058 & 0.076 & 0.073 & 0.109 & 0.094 & 0.144 & 0.092 \\
\hline 13 & Indeno(1,2,3-cd)Pyrene & Five & 0.371 & 0.224 & 0.360 & 0.321 & 0.265 & 0.212 & 0.105 & 0.005 & 0.070 & 0.185 & 0.448 & 0.458 & 0.267 & 0.156 & 0.172 \\
\hline 14 & Dibenez $(a, h)$ anthracene & Five & 0.552 & 0.531 & 0.283 & 0.243 & 0.264 & 0.369 & 0.189 & 0.180 & 0.089 & 0.377 & 0.381 & 0.234 & 0.397 & 1.100 & 0.810 \\
\hline & Total PAH ( Mg/kg) & & 1.872 & 1.54 & 1.888 & 1.137 & 1.556 & 1.471 & 1.529 & 1.012 & 1.112 & 1.516 & 1.958 & 1.679 & 1.879 & 4.625 & 1.595 \\
\hline
\end{tabular}

Table 3:- RAINY season PAH Results (mg/kg)

\begin{tabular}{|c|c|c|c|c|c|c|c|c|c|c|c|c|c|c|c|c|}
\hline $\begin{array}{c}\text { No of } \\
\text { samples }\end{array}$ & $\begin{array}{c}\text { Location } \\
\text { name }\end{array}$ & Nap & Acy & Ace & Flr & Phe & Ant & Flu & Pyr & $\mathrm{BaA}$ & Chr & $\mathrm{BbF}$ & BkFlu & Ipyr & DAnt & $\begin{array}{c}\text { PAH } \\
(\mathrm{mg} / \mathrm{kg})\end{array}$ \\
\hline 5 & $\begin{array}{c}\text { Market } \\
\text { sites }\end{array}$ & 0.012 & 0.013 & 0.052 & 0.03 & 0.017 & 0.009 & 0.018 & 0.027 & 0.011 & 0.42 & 0.22 & 0.087 & 0.308 & 0.375 & 1.599 \\
\hline 5 & $\begin{array}{c}\text { Semi } \\
\text { Indusrial } \\
\text { Sites } \\
\end{array}$ & 0.01 & 0.017 & 0.009 & 0.025 & 0.068 & 0.07 & 0.098 & 0.011 & 0.013 & 0.403 & 0.173 & 0.051 & 0.115 & 0.241 & 1.304 \\
\hline 5 & $\begin{array}{l}\text { Residential } \\
\text { sites }\end{array}$ & 0 & 0.008 & 0.005 & 0.005 & 0.009 & 0.006 & 0.015 & 0.006 & 0.029 & 1.071 & 0.206 & 0.103 & 0.3 & 0.584 & 2.347 \\
\hline 5 & $\begin{array}{c}\text { Control } \\
\text { Sites }\end{array}$ & 0 & 0 & 0 & 0 & 0 & 0.0004 & 0.0004 & 0.0003 & 0.0001 & 0.0019 & 0.0104 & 0.0263 & 0.0037 & 0.0082 & 0.0517 \\
\hline
\end{tabular}

Table 4:- RAINY season Mean / Average PAH(mg/kg) 
ISSN No:-2456-2165

\begin{tabular}{|c|c|c|c|c|c|c|c|c|c|c|}
\hline PAHs & Number & & Market & & & $\begin{array}{c}\text { Semi } \\
\text { Industrial }\end{array}$ & & & Residential & \\
\hline & of Rings & Range & Mean & SD & Range & Mean & SD & Range & Mean & SD \\
\hline Nap & 2 & $0.000-0.055$ & 0.012 & 0.30693 & $0.000-0.048$ & 0.0096 & 0.021466 & $0.000-0.001$ & 0 & 0.000447 \\
\hline Acy & 3 & $0.00-0.039$ & 0.0128 & 0.016438 & $0.000-0.079$ & 0.017 & 0.034756 & $0.000-0.026$ & 0.008 & 0.011524 \\
\hline Ace & & $0.009-0.209$ & 0.0516 & 0.088452 & $0.002-0.017$ & 0.0088 & 0.006458 & $0.003-0.007$ & 0.004 & 0.001673 \\
\hline Flr & 3 & $0.004-0.120$ & 0.0294 & 0.050678 & $0.002-0.093$ & 0.0254 & 0.038331 & $0.002-0.008$ & 0.005 & 0.002121 \\
\hline Phe & 3 & $0.007-0.042$ & 0.0164 & 0.014622 & $0.010-0.229$ & 0.0674 & 0.094495 & $0.004-0.019$ & 0.009 & 0.005941 \\
\hline Ant & 3 & $0.002-0.015$ & 0.0092 & 0.00497 & $0.009-0.274$ & 0.0704 & 0.114378 & $0.003-0.012$ & 0.006 & 0.003564 \\
\hline$\Sigma L M W$ & & $0.022-0.48$ & 0.1314 & 0.48209 & $0.023-0.74$ & 0.1986 & 0.309884 & $0.012-0.073$ & 0.032 & 0.02527 \\
\hline Flu & 4 & $0.010-0.025$ & 0.2204 & 0.007266 & $0.014-0.379$ & 0.0982 & 0.157462 & $0.009-0.027$ & 0.015 & 0.007436 \\
\hline Pyr & 4 & $0.001-0.113$ & 0.42 & 0.048106 & $0.002-0.024$ & 0.0112 & 0.010849 & $0.001-0.018$ & 0.007 & 0.007335 \\
\hline $\mathrm{BaA}$ & 4 & $0.003-0.031$ & 0.011 & 0.01138 & $0.004-0.032$ & 0.0128 & 0.011541 & $0.002-0.106$ & 0.028 & 0.43661 \\
\hline $\mathrm{Chr}$ & 4 & $0.141-0.741$ & 0.0272 & 0.262684 & $0.054-0.296$ & 0.04028 & 0.262345 & $0.418-2.839$ & 1.071 & 0.996562 \\
\hline $\mathrm{BbF}$ & 5 & $0.078-0.420$ & 0.0184 & 0.13054 & $0.065-0.238$ & 0.1728 & 0.0666803 & $0.035-0.342$ & 0.207 & 0.116787 \\
\hline BkFlu & 5 & $0.045-0.145$ & 0.087 & 0.036667 & $0.009-0.079$ & 0.051 & 0.029774 & $0.073-0.144$ & 0.102 & 0.026539 \\
\hline Ipyr & 6 & $0.224-0.371$ & 0.3082 & 0.062743 & $0.005-0.212$ & 0.1154 & 0.084459 & $0.156-0.458$ & 0.3 & 0.14584 \\
\hline Dant & 5 & $0.243-0.552$ & 0.3746 & 0.153194 & $0.089-0.377$ & 0.2408 & 0.126894 & $0.81-1.100$ & 0.584 & 0.359169 \\
\hline$\Sigma$ HMW & & $0.745-2.398$ & 1.4668 & 0.71258 & $0.242-1.637$ & 0.74248 & 0.7500043 & $1.504-5.034$ & 2.314 & 2.096278 \\
\hline EPAHs & & $0.965-2.878$ & 1.5982 & 1.19467 & $0.265-2.377$ & 0.94108 & 1.0598883 & $1.504-5.107$ & 2.346 & 2.121548 \\
\hline
\end{tabular}

Table 5:- RAINY season Range, Mean and SD Concentrations, of PAHs in Market, Semi-Industrial and Residential Areas (mg kg

Ace $=$ acenaphthene, Acy $=$ acenaphthylene, Ant $=$ anthracene, $\mathrm{BaA}$ : benzo[a] anthracene, $\mathrm{BaP}=$ benzo[a]pyrene, $\mathrm{Chr}=$ chrysene, Flu $=$ fluoranthene, Flr $=$ fluorene, Nap $=$ naphthalene, Phe $=$ phenanthrene, $\mathrm{Pyr}=$ pyrene, Nd = Not detected, $\mathrm{SD}=$ Standard deviation, $\sum \mathrm{LMW}=$ sum of low-molecular weight PAHs, $\sum \mathrm{HMW}=$ sum of high-molecular weight PAHs, $\sum \mathrm{PAHs}=$ the sum of LMW and HMW PAHs. Ave: Average concentration of PAHs (_mg/kg).

In rainy season, the total low molecular weight PAHs (LMWPAHs) ranges $0.022-0.48 \mathrm{mg} / \mathrm{kg}$ with mean 0.1314 for market dumpsites, $0.023-0.74 \mathrm{mg} / \mathrm{kg}$ with mean 0.1986 for semi-industrial dumpsites and $0.012-0.073 \mathrm{mg} / \mathrm{kg}$ with mean 0.032 for residential dumpsites. The high molecular weight PAHs (HMWPAHs) ranges $0.745-2.398 \mathrm{mg} / \mathrm{kg}$ with mean $1.466 \mathrm{mg} / \mathrm{kg}$ for market dumpsites, $0.242-1.637 \mathrm{mg} / \mathrm{kg}$ with mean $0.742 \mathrm{mg} / \mathrm{kg}$ for semi- industrial dumpsites and $1.504-5.034 \mathrm{mg} / \mathrm{kg}$ with mean $2.314 \mathrm{mg} / \mathrm{kg}$ for residential dumpsites. The total PAHs ( $\mathrm{PAHs}$ ) concentration values ranges $0.965-2.878 \mathrm{mg} / \mathrm{kg}$ with mean 1.598 for markets dumpsites, $0.265-2.377 \mathrm{mg} / \mathrm{kg}$ with mean $0.94 \mathrm{mg} / \mathrm{kg}$ for semi- industrial dumpsites and $1.504-5.107 \mathrm{mg} / \mathrm{kg}$ with mean $2.346 \mathrm{mg} / \mathrm{kg}$ for residential dumpsites. The control sites have total PAHs of $0.0517 \mathrm{mg} / \mathrm{kg}$. (Table 4.25)

\begin{tabular}{|c|c|c|c|c|c|c|c|c|c|c|c|c|c|c|c|c|c|}
\hline & & & \multicolumn{5}{|c|}{ Market Area } & \multicolumn{5}{|c|}{ Semi - Industrial } & \multicolumn{5}{|c|}{ Residential } \\
\hline & & & \begin{tabular}{|c|} 
Okija \\
Market
\end{tabular} & \begin{tabular}{|c|} 
Creek \\
Road \\
Market
\end{tabular} & $\begin{array}{c}\text { Rumokuta } \\
\text { (Market } \\
\text { area) }\end{array}$ & $\begin{array}{c}\text { Water } \\
\text { side } \\
\text { (Creek } \\
\text { road) }\end{array}$ & \begin{tabular}{|l|} 
Mile 1 \\
Market \\
\end{tabular} & \begin{tabular}{|c|} 
Trans \\
Amadi
\end{tabular} & $\begin{array}{c}\text { Stadium } \\
\text { Road }\end{array}$ & $\begin{array}{c}\text { Odili } \\
\text { Road }\end{array}$ & Elekohia & $\mathrm{D} /$ Line & Borokin & $\begin{array}{c}\text { Marine } \\
\text { Base }\end{array}$ & Elekohia & Diobu & $\begin{array}{c}\text { Rukpokwu } \\
\text { village }\end{array}$ \\
\hline & & & \begin{tabular}{|c|}
$\mathrm{N} 04 \circ$ \\
$47^{\prime}$ \\
$50.5^{\prime \prime}$ \\
E 006o \\
$59^{\prime}$ \\
$54.6^{\prime \prime}$ \\
\end{tabular} & \begin{tabular}{|c|} 
N 04o \\
$45^{\prime}$ \\
$31.5^{\prime \prime}$ \\
E 007o \\
$01^{\prime}$ \\
$33.0^{\prime \prime}$ \\
\end{tabular} & $\mid \begin{array}{c}\text { N 040 51" } \\
58.2^{\prime \prime} \\
\text { E 0070 00 } \\
02.8^{\prime \prime} \\
\end{array}$ & $\begin{array}{c}\text { N 04o } \\
45^{\prime} \\
31.2^{\prime \prime} \\
\text { E 007o } \\
01^{\prime} \\
27.4^{\prime \prime} \\
\end{array}$ & \begin{tabular}{|c|} 
N 04o \\
$47^{\prime}$ \\
$37.2^{\prime \prime}$ \\
E 006o \\
$59^{\prime}$ \\
$43.8^{\prime \prime}$ \\
\end{tabular} & \begin{tabular}{|c|} 
N 04o \\
$49^{\prime}$ \\
$22.7^{\prime \prime}$ \\
E 007o \\
$02^{\prime}$ \\
$22.1^{\prime \prime}$ \\
\end{tabular} & \begin{tabular}{|c|} 
N 04o \\
$49^{\prime}$ \\
$30.9^{\prime \prime}$ \\
E 007o \\
$01^{\prime}$ \\
$29.2^{\prime \prime}$ \\
\end{tabular} & \begin{tabular}{|c|} 
N 04o \\
$48^{\prime}$ \\
$14.2^{\prime \prime}$ \\
E 007o \\
$02^{\prime}$ \\
$57.7^{\prime \prime}$ \\
\end{tabular} & \begin{tabular}{|c|} 
N 04。 \\
$49^{\prime}$ \\
$07.8^{\prime \prime}$ \\
E 007o \\
$01^{\prime}$ \\
$35.0^{\prime \prime}$ \\
\end{tabular} & \begin{tabular}{|c|} 
N 04o \\
$48^{\prime}$ \\
$10.1^{\prime \prime}$ \\
E 007o \\
$00^{\prime}$ \\
$00.8^{\prime \prime}$ \\
\end{tabular} & \begin{tabular}{|c|} 
N 04o \\
$44^{\prime}$ \\
$47.4^{\prime \prime}$ \\
E 007\% \\
$02^{\prime}$ \\
$29.5^{\prime \prime}$ \\
\end{tabular} & \begin{tabular}{|c|} 
N 04o \\
$46^{\prime}$ \\
$17.4^{\prime \prime}$ \\
E 007o \\
$01^{\prime}$ \\
$29.0^{\prime \prime}$ \\
\end{tabular} & $\begin{array}{c}\text { N 04o } \\
49^{\prime} \\
06.2^{\prime \prime} \\
\text { E 007o } \\
01^{\prime} \\
49.4^{\prime \prime} \\
\end{array}$ & \begin{tabular}{|c|} 
N 04o \\
$47^{\prime}$ \\
$33.6^{\prime \prime}$ \\
E 007o \\
$00^{\prime}$ \\
$03.0^{\prime \prime}$
\end{tabular} & $\begin{array}{c}\text { N 04o } 54^{\prime} \\
11.7^{\prime \prime} \\
\text { E 0060 59' } \\
19.0^{\prime \prime} \\
\end{array}$ \\
\hline S/no & PAH name & \begin{tabular}{|c|} 
No of \\
rings
\end{tabular} & MA001 & MA002 & MA003 & MA004 & MA005 & SIA001 & SIA002 & SIA003 & SIA004 & SLA005 & RA001 & RA002 & RA003 & RA004 & RA005 \\
\hline 1 & Naphthalene & Two & 0.000 & 0.000 & 0.000 & 0.000 & 0.000 & 0.000 & 0.000 & 0.000 & 0.000 & 0.000 & 0.000 & 0.000 & 0.000 & 0.000 & 0.000 \\
\hline 2 & Acenaphthylene & Two & 0.000 & 0.000 & 0.000 & 0.000 & 0.000 & 0.000 & 0.000 & 0.000 & 0.000 & 0.000 & 0.000 & 0.000 & 0.000 & 0.000 & 0.000 \\
\hline 3 & Acenaphthene & Two & 0.000 & 0.000 & .000 & 0.000 & 0.000 & 0.000 & 0.000 & 0.000 & 0.000 & 0.000 & 0.000 & 0.000 & 0.000 & 0.051 & 0.000 \\
\hline 4 & Fluorene & Two & 0.000 & 0.000 & 0.000 & 0.000 & 0.000 & 0.140 & 0.003 & 0.000 & 0.000 & 0.000 & 0.000 & 0.000 & 0.012 & 0.002 & 0.013 \\
\hline 5 & Phenanthrene & Three & 0.115 & 0.000 & 0.000 & 0.000 & 0.000 & 0.054 & 0.020 & 0.000 & 0.000 & 0.081 & 0.000 & 0.000 & 0.000 & 0.016 & 0.002 \\
\hline 6 & Anthracene & Three & 0.024 & 0.002 & 0.000 & 0.000 & 0.000 & 0.002 & 0.001 & 0.000 & 0.000 & 0.100 & 0.001 & 0.000 & 0.001 & 0.008 & 0.003 \\
\hline 7 & Fluoranthene & Four & 0.052 & 0.007 & 0.000 & 0.001 & 0.000 & 0.000 & 0.010 & 0.015 & 0.000 & 0.075 & 0.001 & 0.000 & 0.005 & 0.024 & 0.004 \\
\hline 8 & Pyrene & Four & 0.005 & 0.156 & 0.522 & 0.000 & 0.000 & 0.000 & 0.000 & 0.000 & 0.000 & 0.147 & 0.000 & 0.000 & 0.002 & 0.012 & 0.002 \\
\hline 9 & Benz(a)anthracene & Four & 0.005 & 0.060 & 0.074 & 0.248 & 0.000 & 0.000 & 0.000 & 0.008 & 0.000 & 0.114 & 0.001 & 0.000 & 0.003 & 0.008 & 0.002 \\
\hline 10 & Chrysene & Four & 0.012 & 0.053 & 0.034 & 0.157 & 0.210 & 0.000 & 0.001 & 0.060 & 0.000 & 0.027 & 0.003 & 0.000 & 0.005 & 0.003 & 0.000 \\
\hline 11 & Benzo(b)Fluoranthene & Four & 0.025 & 0.201 & 0.125 & 0.108 & 0.404 & 0.000 & 0.003 & 0.069 & 0.000 & 0.048 & 0.003 & 0.000 & 0.004 & 0.005 & 0.000 \\
\hline 12 & Benzo(k)fluoranthene & Four & 0.014 & 0.014 & 0.206 & 0.069 & 0.076 & 0.063 & 0.064 & 0.000 & 0.000 & 0.016 & 0.001 & 0.000 & 0.000 & 0.000 & 0.000 \\
\hline 13 & Indeno(1,2,3-cd)Pyrene & Six & 0.018 & 0.083 & 0.241 & 0.311 & 0.402 & 0.036 & 0.005 & 0.091 & 0.029 & 0.056 & 0.032 & 0.000 & 0.000 & 0.000 & 0.000 \\
\hline 14 & Dibenez $(\mathrm{a}, \mathrm{h})$ anthracene & Five & 0.009 & 0.152 & 0.195 & 0.995 & 0.740 & 0.146 & 0.002 & 0.050 & 0.000 & 0.119 & 0.003 & 0.000 & 0.000 & 0.000 & 0.000 \\
\hline & Total PAH $(\mathrm{Mg} / \mathrm{kg})$ & & 0.279 & 0.729 & 1.4 & 1.89 & 1.834 & 0.44 & 0.11 & 0.426 & 0.03 & 0.783 & 0.045 & 0.000 & 0.034 & 0.129 & 0.003 \\
\hline
\end{tabular}

Table 6:- DRY season PAH Results $(\mathrm{mg} / \mathrm{kg})$ 
ISSN No:-2456-2165

\begin{tabular}{|c|c|c|c|c|c|c|c|c|c|c|c|c|c|c|c|c|}
\hline $\begin{array}{c}\text { No of } \\
\text { samples }\end{array}$ & $\begin{array}{c}\text { Location } \\
\text { name }\end{array}$ & Nap & Acy & Ace & Flr & Phe & Ant & Flu & Pyr & $\mathrm{BaA}$ & Chr & $\mathrm{BbF}$ & BkFlu & Ipyr & DAnt & $\begin{array}{c}\text { PAH } \\
(\mathrm{mg} / \mathrm{kg})\end{array}$ \\
\hline 5 & Market sites & 0 & 0 & 0 & 0 & 0.023 & 0.0052 & 0.012 & 0.1366 & 0.0774 & 0.0932 & 0.1726 & 0.0758 & 0.211 & 0.4182 & 1.225 \\
\hline 5 & $\begin{array}{c}\text { Semi } \\
\text { Industrial } \\
\text { sites }\end{array}$ & 0 & 0 & 0 & 0.03 & 0.031 & 0.0206 & 0.02 & 0.0294 & 0.0244 & 0.0176 & 0.024 & 0.0286 & 0.0434 & 0.0634 & 0.3324 \\
\hline 5 & $\begin{array}{l}\text { Residential } \\
\text { sites }\end{array}$ & 0 & 0 & 0.01 & 0.01 & 0.0036 & 0.0026 & 0.0068 & 0.0032 & 0.0028 & 0.0022 & 0.0024 & 0.0002 & 0.0064 & 0.0006 & 0.0508 \\
\hline 5 & Control sites & $\begin{array}{c}0.004 \\
6\end{array}$ & $\begin{array}{c}0.00 \\
3 \\
\end{array}$ & $\begin{array}{c}0.006 \\
7 \\
\end{array}$ & 0 & 0 & 0.0008 & 0.0018 & 0.0013 & 0.0008 & 0.0009 & 0.0011 & 0.0001 & 0 & 0.0019 & 0.023 \\
\hline
\end{tabular}

Table 7:- DRY Season Mean / Average PAH ( $\mathrm{mg} / \mathrm{kg}$ )

\begin{tabular}{|c|c|c|c|c|c|c|c|c|c|c|}
\hline \multirow{2}{*}{ PAHs } & \multirow{2}{*}{$\begin{array}{l}\text { Number } \\
\text { of Rings }\end{array}$} & & Market & & & $\begin{array}{c}\text { Semi } \\
\text { Industrial }\end{array}$ & & & Residential & \\
\hline & & Range & Mean & SD & Range & Mean & SD & Range & Mean & SD \\
\hline Nap & 2 & $0.000-0.000$ & 0 & 0 & $0.000-0.00$ & 0 & 0 & $0.000-0.000$ & 0 & 0 \\
\hline Acy & 3 & $0.00-0.000$ & 0 & 0 & $0.000-0.00$ & 0 & 0. & $0.000-0.000$ & 0 & 0 \\
\hline Ace & 3 & $0.000-0.000$ & 0 & 0 & $0.000-0.000$ & 0 & 0 & $0.000-0.051$ & 0.01 & 0.02 \\
\hline $\mathrm{Fr}$ & 3 & $0.000-0.000$ & 0 & 0 & $0.000-0.140$ & 0.029 & 0.55 & $0.000-0.013$ & 0.006 & 0.005 \\
\hline Phe & 3 & $0.000-0.115$ & 0.023 & 0.046 & $0.000-0.081$ & 0.031 & 0.031 & $0.000-0.016$ & 0.004 & 0.006 \\
\hline Ant & 3 & $0.000-0.024$ & 0.005 & 0.009 & $0.000-0.100$ & 0.021 & 0.039 & $0.000-0.008$ & 0.003 & 0.002 \\
\hline$\Sigma L M W$ & & & 0.028 & 0.055 & & 0.81 & 0.125 & & 0.023 & 0.033 \\
\hline $\mathrm{Flu}$ & 4 & $0.000-0.052$ & 0.012 & 0.02 & $0.000-0.075$ & 0.02 & 0.028 & $0.000-0.024$ & 0.007 & 0.008 \\
\hline Pyr & 4 & $0.000-0.522$ & 0.137 & 0.201 & $0.000-0.147$ & 0.029 & 0.058 & $0.000-0.012$ & 0.003 & 0.004 \\
\hline $\mathrm{BaA}$ & 4 & $0.000-0.248$ & 0.078 & 0.09 & $0.000-0.114$ & 0.024 & 0.044 & $0.000-0.005$ & 0.003 & 0.001 \\
\hline $\mathrm{Chr}$ & 4 & $0.012-0.210$ & 0.093 & 0.076 & $0.000-0.06$ & 0.018 & 0.023 & $0.00-0.005$ & 0.002 & 0.002 \\
\hline $\mathrm{BbF}$ & 5 & $0.025-0.404$ & 0.173 & 0.128 & $0.000-0.069$ & 0.024 & 0.028 & $0.000-0.001$ & 0.002 & 0.0004 \\
\hline $\mathrm{BkFlu}$ & 5 & $0.014-0.206$ & 0.076 & 0.07 & $0.000-0.064$ & 0.028 & 0.029 & $0.000-0.032$ & 0.006 & 0.012 \\
\hline Ipyr & 6 & $0.018-0.402$ & 0.211 & 0.142 & $0.005-0.091$ & 0.043 & 0.028 & $0.00-0.003$ & 0.006 & 0.001 \\
\hline Dant & 5 & $0.009-0.995$ & 0.418 & 0.38 & $0.000-0.146$ & 0.063 & 0.059 & $0.00-0.045$ & 0.001 & 0.046 \\
\hline इHMW & & & 1.198 & 1.107 & & 0.249 & 0.297 & & 0.03 & 0.0744 \\
\hline EPAHs & & & 1.226 & 1.162 & & 0.33 & 0.422 & & 0.053 & 0.1074 \\
\hline
\end{tabular}

Table 8:- DRY season Range, Mean and SD Concentrations, of PAHs in Market, Semi-Industrial and Residential Areas (mg kg-1)

Ace $=$ acenaphthene Acy $=$ acenaphthylene, Ant $=$ anthracene, $\mathrm{BaA}$ : benzo[a]anthracene, $\mathrm{BaP}=$ benzo[a]pyrene, $\mathrm{Chr}=$ chrysene, Flu $=$ fluoranthene, Flr $=$ fluorene, Nap $=$ naphthalene, Phe $=$ phenanthrene, Pyr $=$ pyrene, Nd $=$ Not detected, SD $=$ Standard deviation, $\sum$ LMW $=$ sum of low-molecular weight PAHs, $\sum H M W=$ sum of high-molecular weight PAHs, $\sum$ PAHs $=$ the sum of LMW and HMW PAHs. Ave: Average concentration of PAHs (_mg/kg)

In dry season, the total low molecular weight PAHs ( LMWPAHs) ranges $0.000-0.115 \mathrm{mg} / \mathrm{kg}$ with mean $0.028 \mathrm{mg} / \mathrm{kg}$ for market dumpsites, $0.000-0.140 \mathrm{mg} / \mathrm{kg}$ with mean $0.81 \mathrm{mg} / \mathrm{kg}$ for semi-industrial dumpsites and $0.000-0.051 \mathrm{mg} / \mathrm{kg}$ with mean $0.23 \mathrm{mg} / \mathrm{kg}$ for residential dumpsites. The high molecular weight PAHs (HMWPAHs) ranges $0.009-0.995 \mathrm{mg} / \mathrm{kg}$ with mean $1.107 \mathrm{mg} / \mathrm{kg}$ for market dumpsites, $0.005-0.147 \mathrm{mg} / \mathrm{kg}$ with mean $0.249 \mathrm{mg} / \mathrm{kg}$ for semi- industrial dumpsites and $0.00-$ $0.045 \mathrm{mg} / \mathrm{kg}$ with mean $0.03 \mathrm{mg} / \mathrm{kg}$ for residential dumpsites. The total PAHs ( $\sum \mathrm{PAHs}$ ) concentration values ranges $0.00-$ $0.995 \mathrm{mg} / \mathrm{kg}$ with mean 1.226 for markets dumpsites, $0.00-0.147 \mathrm{mg} / \mathrm{kg}$ with mean $0.33 \mathrm{mg} / \mathrm{kg}$ for semi- industrial dumpsites and $0.00-0.051 \mathrm{mg} / \mathrm{kg}$ with mean $0.053 \mathrm{mg} / \mathrm{kg}$ for residential dumpsites. The control sites have total PAHs of $0.023 \mathrm{mg} / \mathrm{kg}$. ( Table 4.28) 
Seasonal Variation of Polycyclic Aromatic Hydrocarbons Levels in Soil.

\begin{tabular}{|c|c|c|c|c|c|c|c|c|c|}
\hline & & \multicolumn{2}{|c|}{ Market } & \multicolumn{2}{|c|}{ Residential } & \multicolumn{2}{c|}{ Semi- Industrials } & \multicolumn{2}{c|}{ Control } \\
\hline & & Rainy & Dry & Rainy & Dry & Rainy & Dry & Rainy & Dry \\
\hline Naphthalene & & 0.012 & 0.000 & 0.010 & 0.000 & 0.000 & 0.000 & 0.0000 & 0.0046 \\
\hline Acenaphthylene & & 0.013 & 0.000 & 0.017 & 0.000 & 0.008 & 0.000 & 0.0000 & 0.0030 \\
\hline Acenaphthene & & 0.052 & 0.000 & 0.009 & 0.000 & 0.005 & 0.010 & 0.0000 & 0.0067 \\
\hline Fluorene & & 0.030 & 0.000 & 0.025 & 0.029 & 0.005 & 0.006 & 0.0000 & 0.0000 \\
\hline Phenanthrene & & 0.017 & 0.023 & 0.068 & 0.031 & 0.009 & 0.004 & 0.0000 & 0.0000 \\
\hline Anthracene & & 0.009 & 0.005 & 0.070 & 0.021 & 0.006 & 0.003 & 0.0004 & 0.0008 \\
\hline Fluoranthene & & 0.018 & 0.012 & 0.098 & 0.020 & 0.015 & 0.007 & 0.0004 & 0.0018 \\
\hline Pyrene & & 0.027 & 0.137 & 0.011 & 0.029 & 0.006 & 0.003 & 0.0003 & 0.0013 \\
\hline Benz(a)anthracene & & 0.011 & 0.078 & 0.013 & 0.024 & 0.029 & 0.003 & 0.0001 & 0.0008 \\
\hline Chrysene & & 0.420 & 0.093 & 0.403 & 0.018 & 1.071 & 0.002 & 0.0019 & 0.0009 \\
\hline Benzo(b)Fluoranthene & & 0.220 & 0.173 & 0.173 & 0.024 & 0.206 & 0.002 & 0.0104 & 0.0011 \\
\hline Benzo(k)fluoranthene & & 0.087 & 0.076 & 0.051 & 0.028 & 0.103 & 0.000 & 0.0263 & 0.0001 \\
\hline Indeno(1,2,3-cd)Pyrene & & 0.308 & 0.211 & 0.115 & 0.043 & 0.300 & 0.006 & 0.0037 & 0.0000 \\
\hline Dibenez(a,h)anthracene & & 0.375 & 0.418 & 0.241 & 0.063 & 0.584 & 0.001 & 0.0082 & 0.0019 \\
\hline
\end{tabular}

Table 9:- Average PAHs Concentration at the Dumpsites in RAINY and DRY seasons

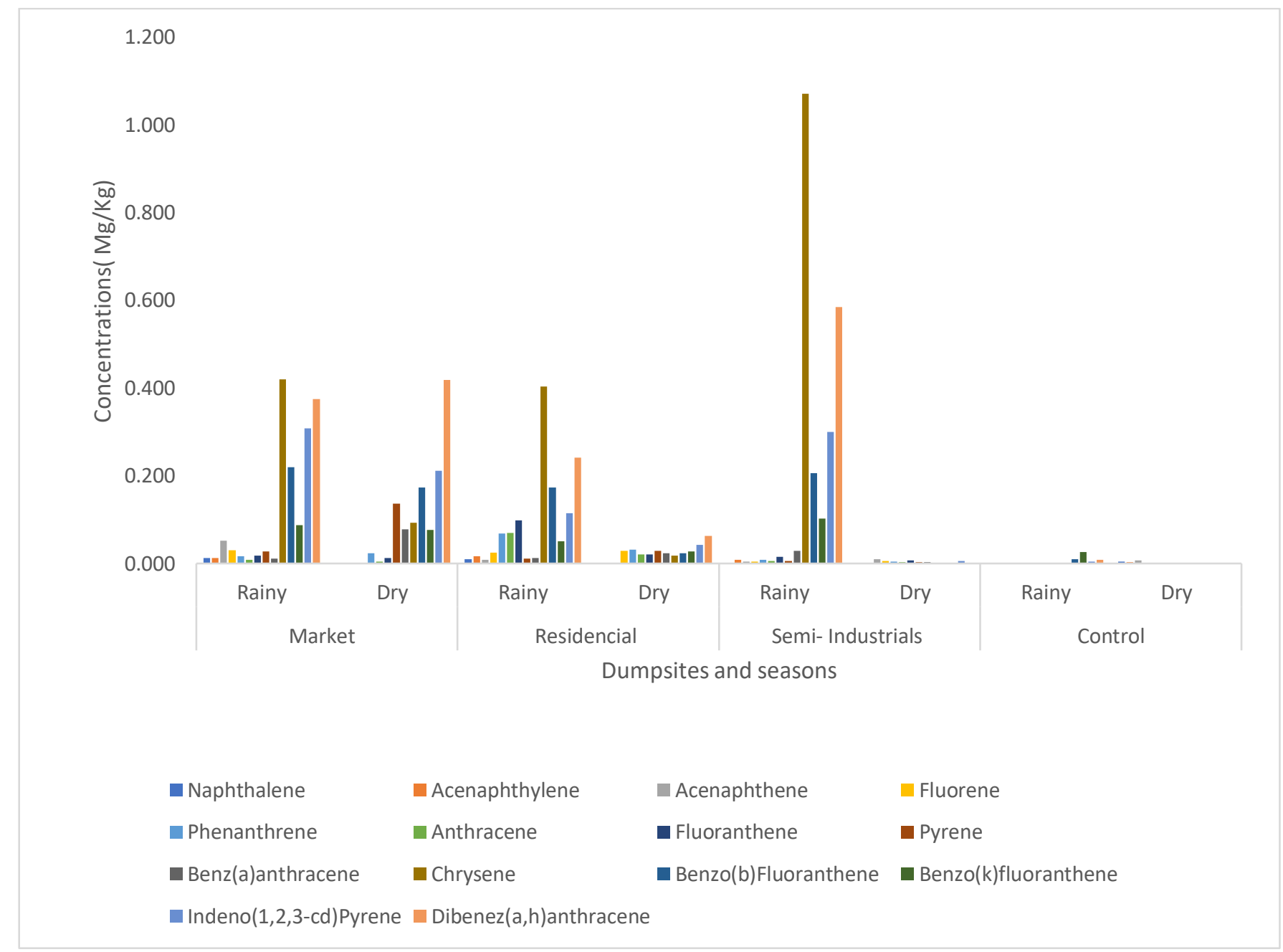

Fig 3:- General graphical comparative analysis of PAHs Concentration at the dumpsites in RAINY and DRY seasons 


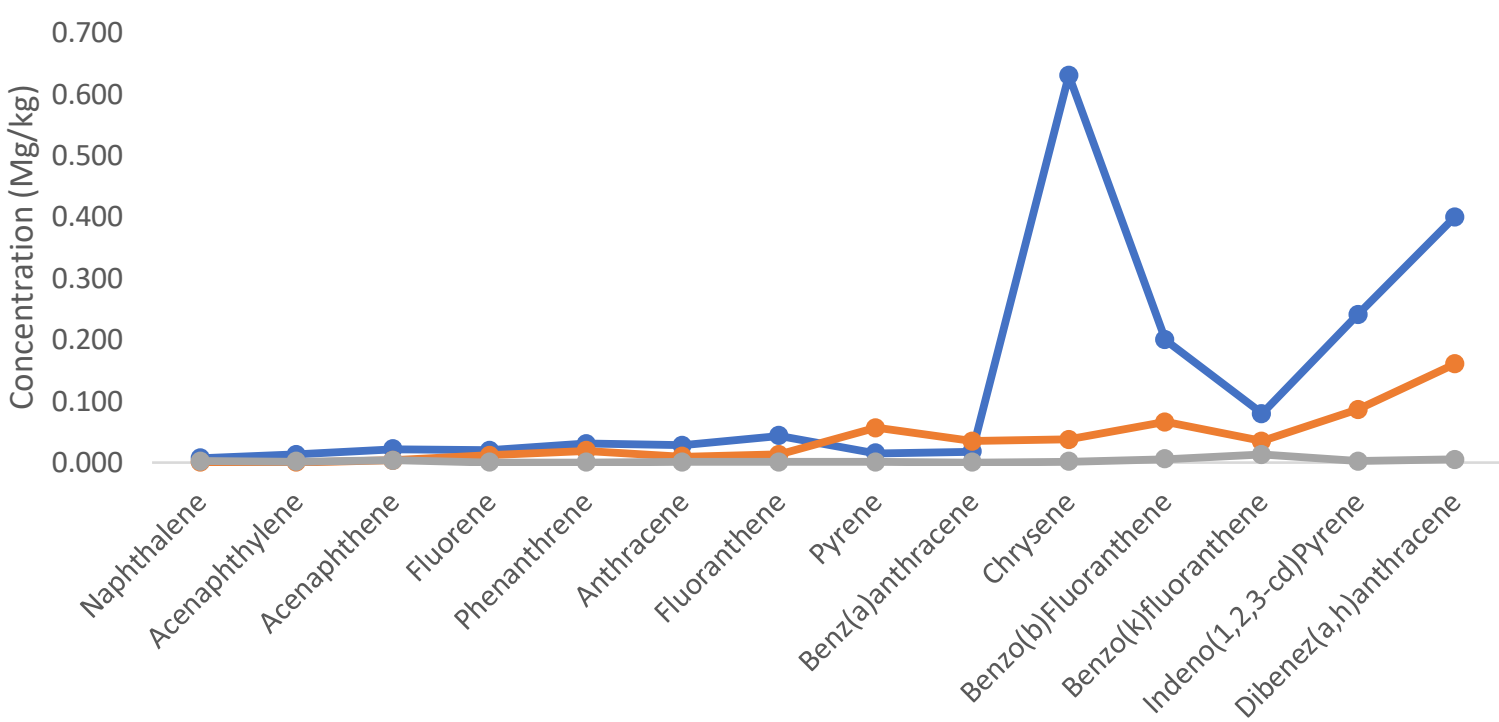

PAHS

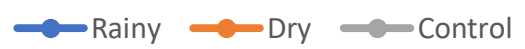

Fig 4:-General Graphical Comparative Analysis of PAHs Concentration at the Dumpsites in RAINY and DRY seasons

Statistical Multivariate Analysis

A 2-sample t-test was carried out in Minitab 18, a statistical software to compare the level of significance between impacted dump sites and control for all locations using $95 \%$ confidence level at $\mathrm{p}=0.05$. The results for the statistical analysis are presented on Table 10 for rainy season and 11 for dry season

\begin{tabular}{|c|c|c|c|}
\hline Comparison & T-value & P-value & Remark \\
\hline Market vs Control & -2.77 & 0.016 & Significant \\
\hline Semi-Industrial vs Control & -3.53 & 0.004 & Significant \\
\hline Residential vs Control & -1.99 & 0.068 & Not significant \\
\hline
\end{tabular}

Table 10:- Summary of 2 Sample t-test Result for PAHs in RAINY season

It was revealed that the residential location is not significantly different from the control site, since $\mathrm{P}>0.05$. However, the semi-industrial and market group showed significant meaning significant difference with the control sites since $\mathrm{p}<0.05$.

\begin{tabular}{|c|c|c|c|}
\hline Comparison & T-value & P-value & Remark \\
\hline Market vs Control Site & -2.71 & 0.018 & No significant \\
\hline Semi-Industrial vs Control Site & -4.44 & 0.001 & No significant \\
\hline Residential vs Control Site & -2.31 & 0.038 & No significant \\
\hline
\end{tabular}

Table 11:- Summary of paired t-test result for PAHs in dry season

\begin{tabular}{|c|c|c|c|c|c|c|}
\hline Comparison & \multicolumn{2}{|c|}{ T-value } & \multicolumn{3}{c|}{ P-value } \\
\hline & Rainy & Dry & Rainy & Remark & Dry & Remark \\
\hline Market \& Control & -2.77 & -2.71 & 0.016 & Significant & 0.018 & Not Significant \\
\hline $\begin{array}{c}\text { Semi-Industrial \& } \\
\text { Control }\end{array}$ & -3.53 & -4.44 & 0.004 & Significant & 0.001 & Not Significant \\
\hline Residential \& Control & -1.99 & -2.31 & 0.068 & Not Significant & 0.038 & Not Significant \\
\hline
\end{tabular}

Table 12:- Seasonal Variation of T-test 
Hierarchical Cluster and Principal Component Analysis

- Hierarchical Cluster Analysis (HCA)

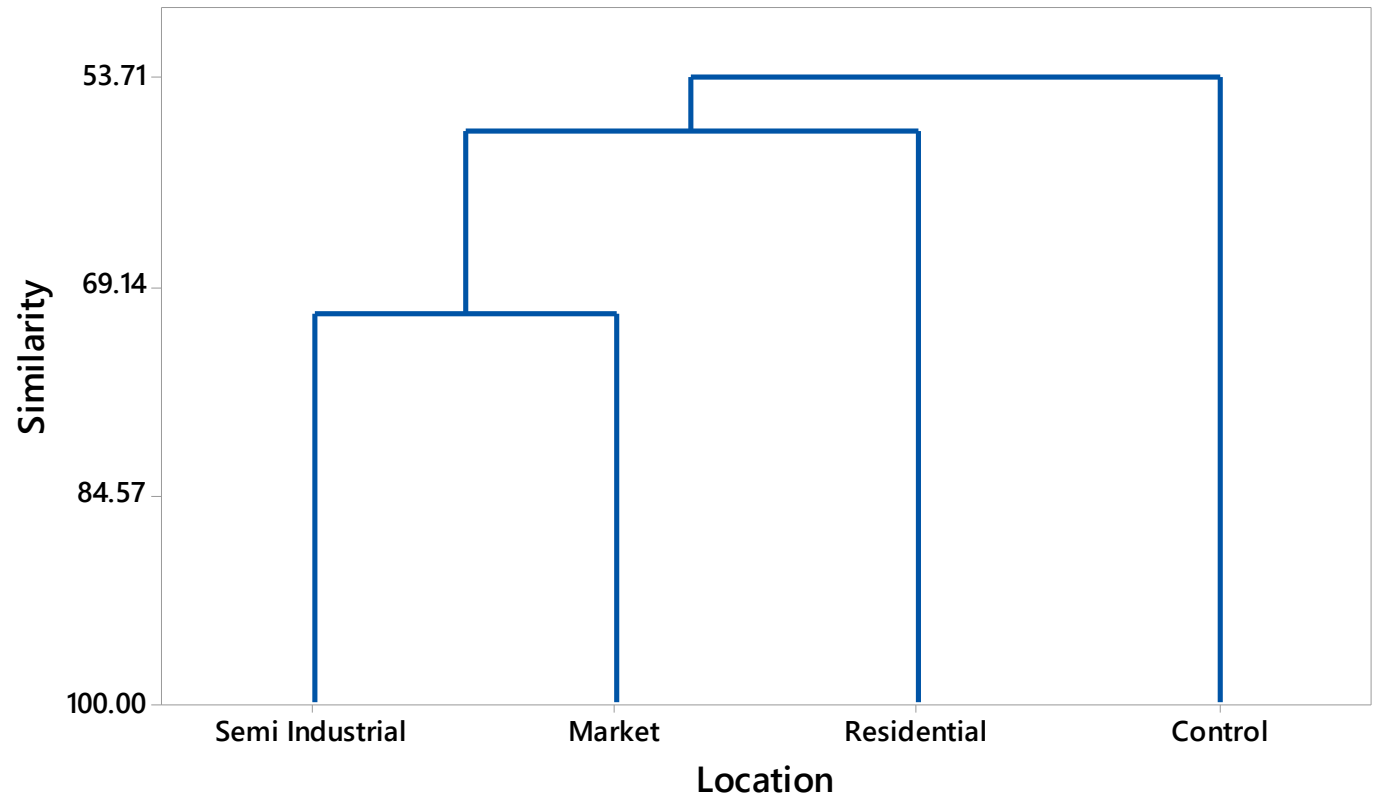

Fig 5:- Dendrogram for PAHs Constituent Distribution using Complete Linkage

Method for Rainy Season

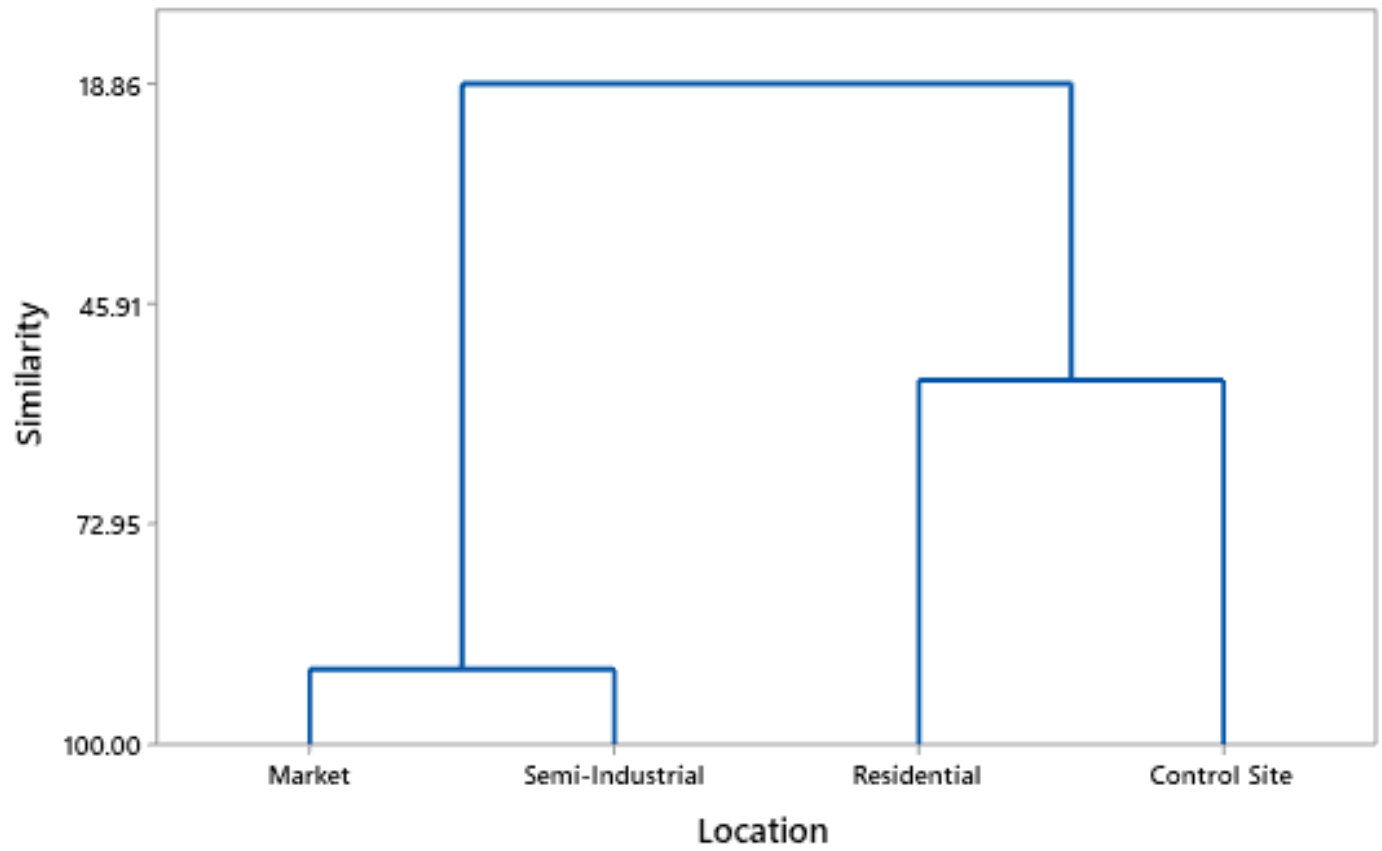

Fig 6:- Dendrogram using Complete Linkage Method in Dry Season

It shows that there are two clusters, market and semi-industrial are in 1 cluster while residential and control site are also in the same cluster. This is an indication that the residential area is more like the control site (see figure 5 and 6) 


\section{Principal Component Analysis (PCA)}

Biplot (axes F1 and F2: $76.90 \%$ )

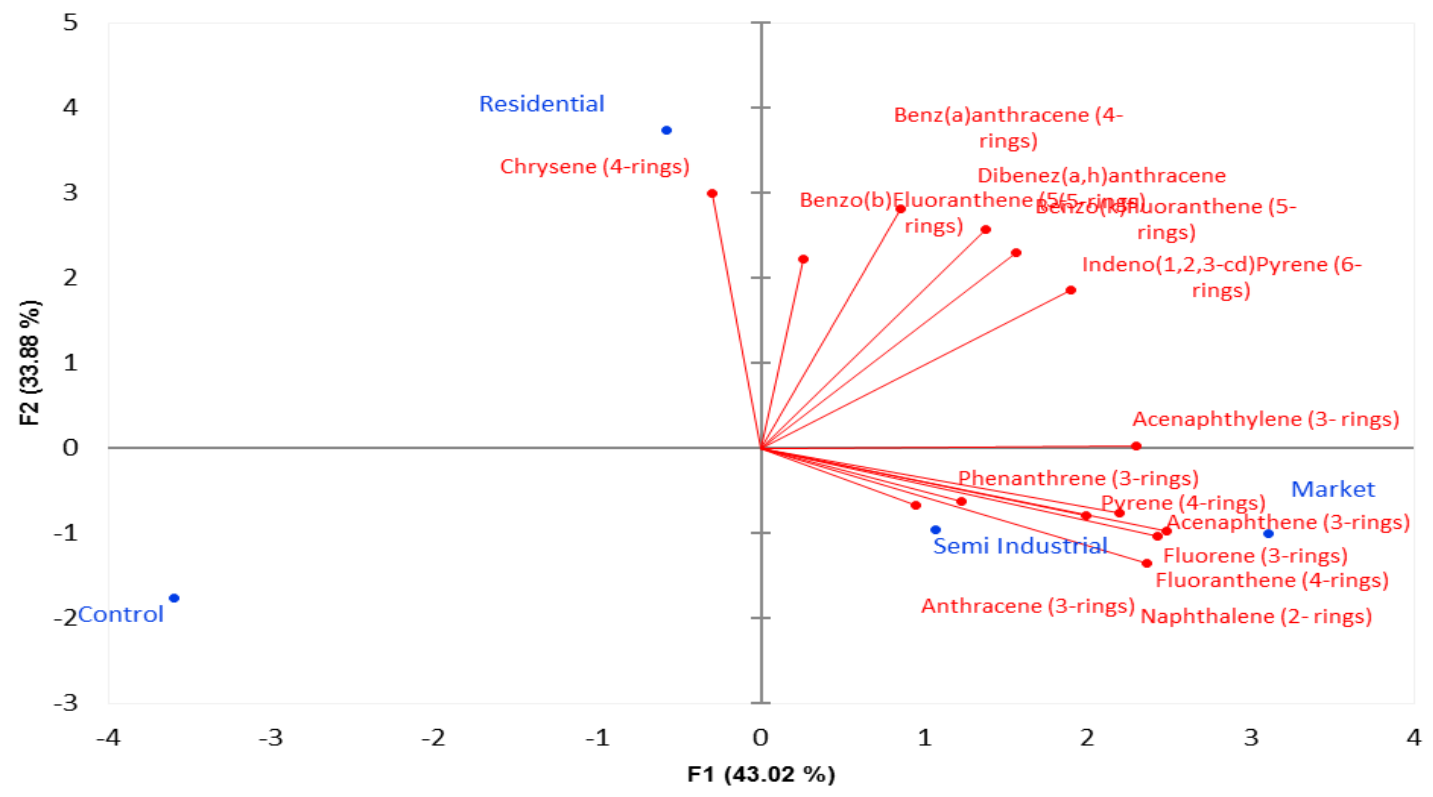

Fig 7:- F Biplot Showing the PAHs Constituents Dumpsites and the Control for Rainy Season

In Fig 7 above, In the four quadrants of the biplot we observe that, in the first quadrant no location was identified. The second quadrant showed only residential, the third quadrant showed the control while the fourth quadrant showed semi-industrial and the market. It was also revealed the only chryene (4-rings) is present in the sencond quadrant most of the PAHs constituents are found in the first quadrant and fewer parameters in the fourth quadrant.

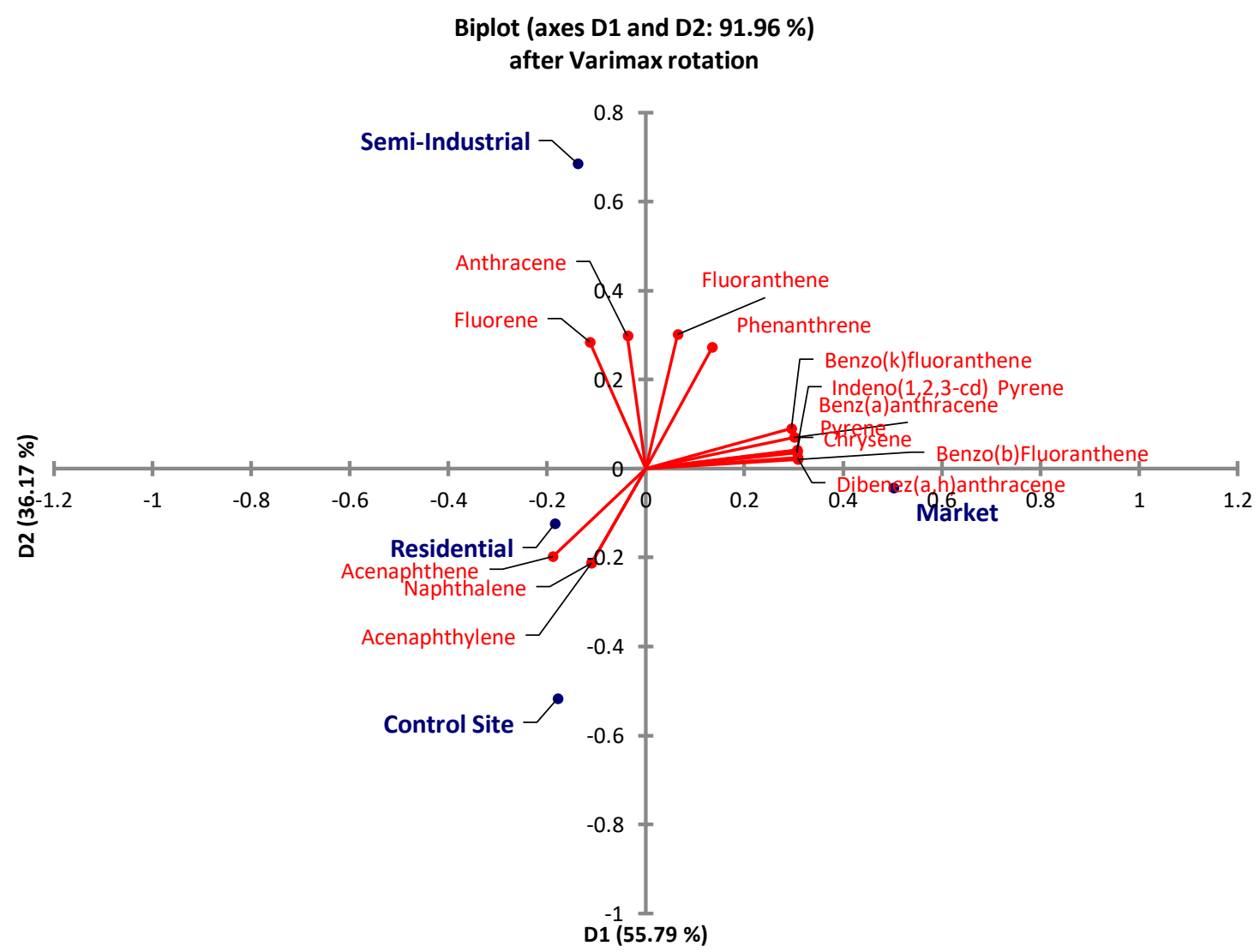

Fig 8:- Biplot of PAHs Constituents and Sampling Locations in Dry Season 
It was observed that semi-industrial area and market area have large positive loadings on component 1 . Therefore, this component focuses on source of contamination of soil with heavy metals, also, all heavy metals analyzed fall within this component, more PAHs constituents are found in this axis. While, the control site and residential area have large negative loadings on component 2. Therefore, this component focuses on very low contamination of PAHs since no very few constituents were found in this axis as shown in Figures 7

\section{DISCUSSION}

The concentration of PAHs in all dumpsites during rainy and dry seasons, indicates that high molecular weight (HMWPAHs) Chrysene, Benzo(b)fluoranthene, Benzo (k) fluoranthene, Indeno(1,2,3cd) pyrene, Diabenez(a,h)anthracene which are highly toxic and cancerous are more in dumpsite located around the residential arears during rainy season while they are predominant in Market dumpsites during dry season. The predominance of HMWPAHs at all the dumpsites in this study also agrees with the work of Ifemeje [5], on Ibadan municipal dumpsites.

The average range, standard deviation and total concentrations of the 14 PAHs are illustrated in Table 5 for rainy season and Table 8 for dry season. For Rainy season, the total concentrations of the PAHs ranged from 0.965 to $2.878 \mathrm{mg} / \mathrm{kg}\left(\sum\right.$ mean $\left.=1.598 \mathrm{mg} / \mathrm{kg}\right)$ for market dumpsites, 0.265 to $2.377 \mathrm{mg} / \mathrm{kg}\left(\sum\right.$ mean $\left.=1.304 \mathrm{mg} / \mathrm{kg}\right)$ for semiindustrial and 1.504 to $5.107 \mathrm{mg} / \mathrm{kg}$ ( $\sum$ mean = $2.346 \mathrm{mg} / \mathrm{kg}$ ) for residential dumpsites. For Dry season, the total concentration of the PAHs ranged from 0.00 to $0.995 \mathrm{mg} / \mathrm{kg} \quad\left(\sum\right.$ mean $\left.=1.226 \mathrm{mg} / \mathrm{kg}\right)$ for markets dumpsites, 0.00 to $0.147 \mathrm{mg} / \mathrm{kg}$ ( $\sum$ mean $=0.33 \mathrm{mg} / \mathrm{kg}$ ) for semi-industrial dumpsites and 0.00 to $0.055 \mathrm{mg} / \mathrm{kg}$ ( $\sum$ mean $=0.053 \mathrm{mg} / \mathrm{kg}$ ) for residential dumpsites. Compared these results to other studies, the Rainy season values are similar to range 1.75 to $2.2 \mathrm{mg} / \mathrm{kg}$ reported for waste dumpsites in Lagos and Ibadan by Adebola[1], while this study dry season results are lower. The range 0.138 to $0.154 \mathrm{mg} / \mathrm{kg}$ reported from soil in Whuan, China by Tekleweini [9], and 0.03 to $0.69 \mathrm{mg} / \mathrm{kg}$ from surface soil Ibadan by Fagbote [3], are far lower that the values on this study. The summed mean PAHs concentrations in this study was markedly lower than the results of Olajire[7], Godson[4] studies on hydrocarbon polluted surface soil in Niger delta because this study was conducted on solid household waste dumpsites. In addition to the above, the concentration of PAHs varies with location, meteorological conditions, photochemical processes, and distance from road networks. Thus, the lower concentration of PAHs in the surface soil layer may also due to the limited additions from surface runoff, rain washout, dry atmospheric particle deposition, garbage incineration, road traffic, and asphalt pavements. It should also be noted that the concentration and distribution of PAHs were mainly related to the degree of economic development, population density, climatic conditions, and soil organic matter, and the divergence of regional economic patterns and climatic conditions was the main reason for the observed PAH distribution in the soils. Traffic emissions, coal and biomass combustion mainly contributed to the PAH contamination of surface soil during the process of urbanization and industrialization,

According to Sun[8], there are four proposed threshold $\sum$ PAHs contamination levels for soil: not contaminated $(<0.200 \mathrm{mg} / \mathrm{kg})$, weakly contaminated $(0.2-$ $0.6 \mathrm{mg} / \mathrm{kg})$, contaminated $(0.6-1.0 \mathrm{mg} / \mathrm{kg})$, and heavily contaminated $(>1.0 \mathrm{mg} / \mathrm{kg})$. According to these classifications, the values of $\sum$ PAHs during rainy season in Markets, Semi- industrial and Residential dumpsites are $1.599 \mathrm{mg} / \mathrm{kg}, 1.304 \mathrm{mg} / \mathrm{kg}$ and $2.347 \mathrm{mg} / \mathrm{kg}$ respectively are all "Heavily contaminated" classification. However during dry season, only the $\sum$ PAH level in Market dumpsites ( $1.225 \mathrm{mg} / \mathrm{kg}$ ) is classified 'Heavily contaminated" while Semi- industrial and Residential with values $0.33 \mathrm{mg} / \mathrm{kg}$ and $0.05 \mathrm{mg} / \mathrm{kg}$ respectively are classified and weekly contaminated. Moreover, the order of the level of pollution in rainy season is observed to be: Control site $<$ Semiindustrial area $<$ Market area < Residential area is highly polluted (HP). the Market area is moderately polluted (MP) while the Semi-industrial area is less polluted (LP). While for Dry Season, the order of the level of pollution is Control site $<$ Residential area $<$ Semi-industrial area $<$ Market area or the Market area is highly polluted (HP), the Semi-industrial area is moderately polluted (MP) while the residential area is less polluted (LP). This study shows that presence of $\mathrm{PAH}$ in all dumpsite where municipal, domestic household solid waste are dumped and thus indicated that the properties and qualities of the soil in these areas are adversely affected.

It was revealed from paired t-test for rainy season, that the residential location is not significantly different from control sites, since $\mathrm{P}>0.05$ while the market and Semiindustrial dumpsites shows significant meaning significant difference with the control sites since $\mathrm{p}<0.05$. However, in Dry season, all the dumpsites show no significant difference from the control sites.

Hierarchical Cluster Analysis and Principal Component Analysis where applied on the measured data to determine the sources of contamination as well as the level of pollution by comparing with the control site. Fig. 4. and 5. shows the Hierarchical Cluster Analysis for rainy and dry seasons respectively. The similarity between the level of pollution between the control site and all other dumpsites is Low; 53.71 for rainy season and 18.86 for dry season. However, market and Semi- industrial dumpsites shows high similarities between each other; 64.17 for rainy season and 88 for dry season.

The Principal component Analysis that is being used to determine the level of pollution are shown in Fig. 6 for rainy season and 7 . for dry season. It confirms that markets and semi- industrial sites are similarly polluted in rainy season while in dry season, markets dumpsites are more polluted than other dumpsites. This confirms the 'Heavy pollution 'status. 


\section{CONCLUSIONS}

$\begin{aligned} & \text { High Molecular weight Polycyclic } \\ & \text { (HMWPAHs) }\end{aligned} \begin{array}{r}\text { Aromatic } \\ \text { Chrysene, }\end{array}$
$\begin{aligned} & \text { Hydrocarbons } \\ & \text { Benzo(b)fluoranthene, Benzo (k) fluoranthene, }\end{aligned}$
Indeno(1,2,3cd)pyrene, Diabenez(a,h)anthracene which are
highly toxic and cancerous are more in dumpsite located
around the residential arears during rainy season while they
are predominant in Market dumpsites during dry season.

According to classification by Sun [8], the sum total value of Polycyclic Aromatic Hydrocarbon $\sum$ PAHs 'Heavily contaminated" the soil at all the dumpsites in Rainy season. However during dry season, only the PAH level in Market dumpsites is classified 'Heavily contaminated"' while Semi- industrial and Residential are classified weekly contaminated. It is recommended that solid waste evacuation should be done frequently from all the dumpsites to the main government reserved dumpsites.

\section{ACKNOWLEDGEMENT}

I wish to acknowledge the Institute of Geo - Science and Space Technology for the opportunity and encouragement for this research.

\section{REFRENCES}

[1]. Adebola, A.A., Peter, O. (2017) Heavy Metals and Polycyclic Aromatic Hydrocarbons in Soil from EWaste Dumpsites in Lagos and Ibadan, Nigeria. Journal of Health and Pollution, 7(15), 71-84.

[2]. ATSDR, (1999). Atlanta, GA: US Department of Health and HumanServices, Agency for Toxic Substances and Disease Registry.: http://www.atsdr.cdc.gov/toxprofiles/tp46-p.pdf

[3]. Fagbote, Olubunmi E., and Edward, O. Olanipekun (2013 ), Polycyclic Aromatic Hydrocarbons (PAHs) and Polychlorinated Biphenyls (PCBs) in Soils of Agbabu, Nigeria. 1st Annual International Interdisciplinary Conference, AIIC 2013, 24-26 April, Azores, Portugal.

[4]. Godson, R. Ana1, E. Mynepalli, K. Sridhar, C. Godwin, O. Emerole. ( 2009). A comparative assessment of soil pollution by polycyclic aromatic hydrocarbons in two Niger Delta communities Nigeria. African Journal of Pure and Applied Chemistry, 3 (3), 031-041.

[5]. Ifemeje, 1 J.C. Udedi, S.C. Lukong, C.B. Okechukwu, A.U. Egbuna, C. ( 2014). Distribution of Polycyclic Aromatic Hydrocarbons and Heavy Metals in Soils from Onisha Municipal Solid Waste Landfill, Nigeria. British Journal of Applied Science \& Technology 4(36), 5058-5071

[6]. Khan, Q. Cao., Zheng, Y.M., Huang, Y.Z., Zhu, Y.G.( 2008). Health Risks of Heavy Metals in Contaminated Soils and Food Crops Irrigated with Wastewater in Beijing, China. Journal of Environmental Pollution. 152(3),686-692,
[7]. Olajire, A.Brack,W ( 2005). Polycyclic aromatic hydrocarbons in Niger Delta contamination sources and profiles. Journal of Environmental Science \& Technology, 2 ( 4), 343-352.

[8]. Sun, C.; Zhang, J.; Ma, Q.; Chen, Y.; Ju, H.( 2017) Polycyclic Aromatic Hydrocarbons (PAHs) in Water and Sediment from a River Basin: Sediment-Water Partitioning, Source Identification and Environmental Health Risk Assessment. Environ. Geochem. Health, 39, 63-74.

[9]. Tekleweini,G. Ababo,W.Xiaoning,L. Xue,Y. Jun,W.(2018). Occurrence and Ecological and Human Health Risk Assessment of Polycyclic Aromatic Hydrocarbons in Soil from Wuhan,Central China. International Jounal of Enviromemtal reserch and public Health. (15).2751. 4-6

[10].Tiri, A., Lahbari, N., and Boudoukha A. (2016). Assessment of the Quality of Water by Hierarchical Cluster and Variance Analyses of the Koudiat Medouar Watershed, East Algeria. Appl. Water Sci. 10.1007/s13201-014-0261-z. 